\title{
The Promise of German Criminal Law: A Science of Crime and Punishment
}

\author{
Markus Dubber \\ Version Publisher's Version \\ Citation Markus Dubber, "The Promise of German Criminal Law: A Science of \\ (published version) Crime and Punishment” (2005) 6 German Law Journal 1049.
}

How to cite TSpace items

\begin{abstract}
Always cite the published version, so the author(s) will receive recognition through services that track citation counts, e.g. Scopus. If you need to cite the page number of the author manuscript from TSpace because you cannot access the published version, then cite the TSpace version in addition to the published version using the permanent URI (handle) found on the record page.
\end{abstract}

This article was made openly accessible by $U$ of $T$ Faculty. Please tell us how this access benefits you. Your story matters. 


\title{
The Promise of German Criminal Law
}

\author{
Markus Dirk Dubber*
}

Introduction

This article takes a critical look at German criminal law theory from an AngloAmerican perspective. It seeks both to capture the basic conception of criminal law as science that has shaped the project of German criminal law theory for centuries and to investigate two of its key accomplishments: its theory of punishment ("positive general prevention") and its theory of criminalization (the theory of "legal goods"). ${ }^{1}$

German criminal law theory enjoys widespread influence in the civil law world. Its impact extends from European countries like Spain, Portugal, Croatia, Greece, Turkey, Austria, Switzerland, Finland, and Sweden, to Israel and the Spanish and Portuguese speaking countries of Latin America, and to Asian countries like Taiwan, South Korea, and Japan.

By contrast, criminal law in common law countries has, until fairly recently, developed largely independent of German influence. Since the completion of the Model Penal Code in 1962, however, interest in German criminal law theory among AngloAmerican criminal law scholars, in the U.S. and elsewhere, has grown steadily. ${ }^{2}$ George Fletcher's Rethinking Criminal Law, in particular, has been remarkably successful in introducing basic concepts of German criminal law into Anglo-American criminal law discourse and doctrine. ${ }^{3}$

\footnotetext{
* Professor of Law \& Director, Buffalo Criminal Law Center, SUNY Buffalo, <dubber@buffalo.edu>. Thanks for comments and suggestions to many colleagues in the U.S. and Germany, in particular Guyora Binder, Sara Faherty, Tatjana Hörnle, Cornelius Nestler, Jacqueline Ross, Bernd Schünemann, and Marianne Varwig. I am also grateful to the Alexander-von-Humboldt Foundation for supporting my research during several stays at the Institute for Legal Philosophy, University of Munich.

${ }^{1}$ Diethelm Kienapfel, Strafrecht: Allgemeiner Teil 39 (4th ed. 1984) (theory of the Rechtsgut "one of the immovable cornerstones of German criminal law doctrine").

${ }^{2}$ See generally G.O.W. Mueller, Comparative Criminal Law in the United States (1970). The drafters of the Model Penal Code were not particularly interested in German criminal law. Eager to devise a piece of model legislation with a chance of adoption in American jurisdictions throughout the land, they instead turned to existing American law, and the common core of the common law tradition, English law. And so the main foreign contributor to the Model Code effort was not a leading German criminal scholar of the day, but Glanville Williams, the man widely regarded as the father of modern English criminal law. It is no accident that the publication of Williams's groundbreaking work, Criminal Law: The General Part, coincided with the drafting of the Model Code from 1952 to 1962. Glanville Williams, Criminal Law: The General Part (1st ed. 1953; 2d ed. 1961). Still, even the Model Code drafters occasionally turned their attention to the Continent and its civil law system, and therefore to Germany. For citations to the German criminal code in the official Commentaries to the Model Code, see, e.g., Model Penal Code Commentaries $\S 3.02$, at $11, \S 210.3$, at 65 (1985).

${ }^{3}$ George P. Fletcher, Rethinking Criminal Law (1978); see also Paul H. Robinson, Criminal Law Case Studies 102-05 (2000) (German theory of self-defense); Alan C. Michaels, Acceptance: The Missing Mental State, 71 S. Cal. L. Rev. 953, 1025-28 (1998) (German theory of intent); Joshua Dressler, Understanding Criminal Law 69 (2d ed. 1995) (German theory of actus reus); Paul H. Robinson, Fundamentals of Criminal Law 488-90 (2d ed. 1995) (German theory of self-defense); Claire O.
} 
The feature of German criminal law theory that is perhaps most familiar to AngloAmerican scholars is the three-step analysis of criminal liability (Straftatsystem). The tripartite (or "structured") system of analysis appears in American casebooks, textbooks, ${ }^{5}$ and court opinions, ${ }^{6}$ though its German origins are not always acknowledged.

Developed in the early twentieth century, the Straftatsystem distinguishes between three levels of inquiry: satisfaction of all offense elements as defined in the statute (Tatbestandsmäßigkeit), wrongfulness (Rechtswidrigkeit), and culpability (Schuld). ${ }^{7}$ This general analytic system applies to all questions of criminal liability, no matter what the offense. Underlying it is the notion that there is such a thing as a general part of criminal law - and of a criminal code - that contains the general principles of criminal liability governing all offenses defined in the criminal law - and the criminal code's - special part. The common law of crimes, by contrast, concerned itself with crimes, as its name suggests. Such "general part" matters as self-defense, public duty, law enforcement, and crime prevention were instead thought of as questions of the law of particular offenses, most importantly homicide. ${ }^{8}$

Under the German tripartite system, the inquiry into criminal liability begins with the special part. Once a potentially applicable offense definition has been found there - say, because someone has intentionally caused the death of another human being, thus satisfying the definition of murder, at least on its face - the inquiry proceeds to the second level, wrongfulness. Here the question is whether the conduct in question was not only facially criminal, but unlawful (or wrong, in a legal sense - rechtswidrig, contrary to law) as well. ${ }^{9}$ In terms of Anglo-American criminal law, the question is whether the conduct is justifiable. (So, to stick with our example, the question might be whether the accused killed in self-defense, i.e., in order to prevent a deadly unlawful attack against him.)

Eventually, assuming the conduct matches the definition of some offense and is unlawful, the inquiry turns to the third, and final, step, which homes in on the actor's responsibility for her concededly criminal and unlawful conduct. Here Anglo-American criminal law, with its traditional procedural approach, considers whether the defendant can raise an excuse "defense." (For instance, instead of claiming self-defense as

Finkelstein, Duress: A Philosophical Account of the Defense in Law, 37 Ariz. L. Rev. 251, 273-75 (1995) (German theory of necessity as justification and as excuse). Examples from the English criminal law literature include Antony Duff, Theories of Criminal Law, in The Stanford Encyclopedia of Philosophy (Edward N. Zalta ed. 2002) (German theory of Rechtsgut); Andrew von Hirsch, Der Rechtsgutsbegriff und das "Harm Principle," 149 Goltdammer's Archiv für Strafrecht 2 (2002) (same).

${ }^{4}$ A leading casebook, Kaplan/Weisberg/Binder, contrasts the "Model Penal Code Scheme" with the "German Scheme." John Kaplan et al., Criminal Law: Cases and Materials 18-20 (3d ed. 1996).

${ }^{5}$ See, e.g., Markus D. Dubber, Model Penal Code passim (2002).

${ }^{6}$ See, e.g., Spunaugle v. State, 946 P.2d 246 (Ct. Crim. App. Okla. 1997); United States v. Lopez, 662 F. Supp. 1083 (N.D. Cal. 1987); State v. Leidholm, 334 N.W.2d 811 (N.D. 1983);

${ }^{7}$ For an excellent English-language exposition of the Straftatsystem by a leading German criminal law scholar, see Wolfgang Naucke, An Insider's Perspective on the Significance of the German Criminal Law Theory's General System for Analyzing Criminal Acts, 1984 BYU L. Rev. 305.

${ }^{8}$ Self-defense, for instance, originally was treated as part of the law of homicide, rather than as a general defense to all crimes. Homicide se defendendo was a type of "excusable homicide." 4 William Blackstone, Commentaries on the Laws of England 182 (1769).

${ }^{9}$ Here the doctrine plays on the ambiguity of the German term Recht, which includes both positive law and law general speaking (or "right"). To be punishable the conduct must be contrary to law (rechtswidrig), rather than merely contrary to the statute (gesetzeswidrig). 
justification, the accused might be entitled to the insanity defense on the ground that he cannot be held responsible for his criminal and unlawful conduct because he lacked some minimum capacity to appreciate the wrongfulness of his conduct or to exercise sufficient self-control.)

Instead of focusing on the much-discussed tripartite analysis of criminal liability and the concomitant distinction between justifications and excuses, this article highlights two other contributions of German criminal law theory: the punishment theory of positive general prevention (positive Generalprävention) and the theory of criminalization according to which the function of criminal law is the protection of legal goods (Rechtsgüter). These aspects of German criminal law theory should prove of particular interest to Anglo-American criminal lawyers. Anglo-American punishment theory has been stuck in a conceptual rut for quite some time, with battle-weary consequentialists (who advocate punishment for the sake of some beneficial consequence, such as crime reduction) and retributivists (who prefer punishment for its own sake, as a matter of "just deserts") continuously reenacting a conflict that has advanced little since the days of Beccaria and Bentham. ${ }^{10}$ Anglo-American theories of crime, as opposed to theories of punishment, are not so much tired as they are nonexistent. While there is a general sense that not every moral wrong should make a crime-notwithstanding legal moralists like Michael Moore ${ }^{11}$ —and that "victimless" crimes are problematic, there is little in the way of an account of the function of criminal law within a system of law in general. ${ }^{12}$

Part I lays the foundation for the exploration of these topics by providing an introductory overview of the project of German criminal law theory. This project cannot be properly understood without an appreciation of its origins as a branch of German legal science, constructed by legal scientists (i.e., law professors) who traditionally have viewed themselves as engaged in the pursuit of truth. In a juryless system, generations of German criminal law scholars have developed a complex and highly formalistic taxonomy of concepts that are applied by professional judges to particular cases, each of which requires a written rationale.

Parts II \& III then treat two "discoveries" of German criminal legal science in greater detail. Part II deals with positive general prevention, a theory of punishment designed to move the debate about rationales for punishment beyond the age-old conflict between consequentialists and retributivists. Part III investigates the concept of legal good, which plays a central role in German criminal law, both as the foundation of the system of criminal law as a whole (which is said to have the sole function of protecting legal goods) and as a useful guidepost in the interpretation of criminal statutes (each of which is regarded as protecting some legal good).

\section{Criminal Law as Science}

\footnotetext{
${ }^{10}$ See Cesare Beccaria, An Essay on Crimes and Punishments (1764); Jeremy Bentham, An Introduction to the Principles of Morals and Legislation (1789).

${ }^{11}$ Michael Moore, Placing Blame 754 (1997) ("all and only moral wrongs should be prohibited by the criminal law, for the reason that such actions (or mental states) are wrongful (or culpable) and deserve punishment").

${ }_{12}$ Paul Robinson is interested not so much in the function of criminal law as a mode of state governance as in the functions of various doctrines within a system of (substantive) criminal law. See Paul Robinson, Structure and Function in Criminal Law (1997).
} 
An eminent Spanish criminal law scholar recently praised the German system of criminal law as "an imposing construct that must be considered one of the great achievements of the human sciences." 13 The results of two centuries of German criminal law theorizing, and of well over a century of concerted doctrinal systematizing (beginning in earnest with the creation of the German Empire and its German Criminal Code in 1871), are indeed impressive. Assembled by generations of scholars and their stable of assistants, who themselves join the professoriate after producing - as is the German custom - two book-length monographs on a criminal law subject, the German system of criminal law is unparalleled in comprehensiveness and complexity. ${ }^{14}$

The serious and sustained attention criminal law theory has received in Germany stands in stark contrast to the general, and much-bemoaned, neglect of this subject in Anglo-American jurisprudence, which traditionally has taken a greater interest in matters of private law and, at least in the United States, of constitutional law. ${ }^{15}$

It's not uncommon, in fact, to find German criminal law defining itself, and occasionally its scientific achievements, ${ }^{16}$ in explicit contrast to Anglo-American criminal law. A popular treatise, for example, justifies the very project of German criminal law doctrine by citing the famous 19th-century English case of Dudley \& Stephens, about murder and cannibalism after a shipwreck on the high seas. ${ }^{17}$ We need a theory of crime that attempts to "theoretically capture punishable conduct in its entirety through the enumeration of general characteristics," the authors explain, precisely because without it the "solution of this case remains uncertain and dependant upon

\footnotetext{
${ }^{13}$ Enrique Gimbernat Ordeig, Sind die bisherigen dogmatischen Grunderfordernisse eines Allgemeinen Teils geeignet, dem heutigen Stand der Kriminalität, der Strafzumessung und des Sanktionensystems zu genügen, in Krise des Strafrechts und der Strafrechtswissenschaften?, at 152, 165 (Hans-Joachim Hirsch ed. 2001). It's no accident that high praise for the German system of criminal law would come from a Spanish professor of criminal law. German criminal law by and large has been a professorial affair, as we'll see in greater detail below. What's more, Spanish (and Portuguese) professors, along with their Latin American colleagues, have long been among its most ardent foreign admirers, followed by scholars from Japan, Korea, and Taiwan, with other adherents in Scandinavia, Eastern and Southern (but not Western) Europe, and the Mediterranean. German criminal law textbooks, in translation, continue to play an important role in the criminal law curriculum at Spanish universities. See, e.g., Claus Roxin, Strafrecht: Allgemeiner Teil I, at vii (3d ed. 1997) (translated into Spanish, Portuguese, Japanese); see also HansHeinrich Jescheck \& Thomas Weigend, Lehrbuch des Strafrechts: Allgemeiner Teil iv (5th ed. 1996) (Spanish \& Japanese); Johannes Wessels, Strafrecht: Allgemeiner Teil iv (23d ed. 1993) (Spanish, Portuguese, Korean). On the history and scope of the influence of German criminal law in Spain, see José Cerezo Mir, Die deutsche Strafrechtswissenschaft aus spanischer Sicht, in Die deutsche Strafrechtswissenschaft vor der Jahrtausendwende 255 (Albin Eser et al. eds. 2000); see also Maria KaiafaGbandi, Ein Blick auf Brennpunkte der Entwicklung der deutschen Strafrechtsdogmatik vor der Jahrtausendwende aus der Sicht eines Mitglieds der griechischen Strafrechtswissenschaft, in id. at 261 (Greece).

${ }^{14}$ See Hans-Heinrich Jescheck \& Thomas Weigend, Lehrbuch des Strafrechts: Allgemeiner Teil 199 (5th ed. 1996) (continuing effort "to improve and to supercede" German criminal law through "renovations of the doctrinal edifice").

${ }^{15}$ See, e.g., George P. Fletcher, The Fall and Rise of Criminal Theory, 1 Buff. Crim. L. Rev. 275 (1998).

${ }^{16}$ See, e.g., Bernd Schünemann, Die deutsche Strafrechtswissenschaft nach der Jahrtausendwende, 148 GA 205 (2001) (reviewing Die deutsche Strafrechtswissenschaft vor der Jahrtausendwende: Rückbesinnung und Ausblick (Albin Eser et al. eds. 2000)).

${ }^{17}$ (1884) 14 QBD 273 (CCR).
} 
emotional considerations."18 The English judges would have been better off, so the argument goes, had they enjoyed the benefit of the tripartite analysis of criminal law developed by German criminal law theory, with its "differentiation of the concept of crime into offense definition, illegality, and guilt and the further distinctions connected to it, such as that between necessity as a justification and as an excuse."19 Had they not proceeded upon the - it turns out, incorrect - assumption that necessity could only justify, but not excuse, the authors suggest, the English judges would have solved the case correctly, namely by acquittal on the ground of necessity as an excuse, rather than sentencing the defendants to death for murder, only to see the sentence reduced to six months by way of royal pardon later on.

The notion that there could be such a thing as a correct solution to a case, which might be correct or not, is of course foreign to Anglo-American law, which instead emphasizes that there are always different ways of analyzing a case, and different ways of resolving it, depending not only on the formulation of the relevant legal norms but also, equally important, on the statement of the facts of the case. Similarly unfamiliar is the idea that a system of criminal law would qualify as a scientific accomplishment. These two features of German criminal law are related: there is a solution to every case because law is a science. It is the job of a system of criminal law, as a body of scientific knowledge, to solve cases.

That the study of German criminal law traditionally has been considered a science ${ }^{20}$ is a fundamental fact that is easily overlooked both because it is so alien to an AngloAmerican lawyer and because it is so obvious to her German colleague. German jurisprudence regards all of law as a science (Rechtswissenschaft), and criminal law as one of its branches (Strafrechtswissenschaft) - the others are civil law and public law. ${ }^{21}$ There was a time when Anglo-American jurisprudence too considered itself a science, with law libraries as its laboratories. ${ }^{22}$ But that time has passed so long ago, and the idea of a legal science was laid to rest to so insistently and completely by the Legal Realists of the 1920s and 1930s, that few Anglo-American lawyers even remember it. ${ }^{23}$ Today whatever is scientific about law is borrowed from the unquestioned (or at least less

\footnotetext{
${ }^{18}$ Hans-Heinrich Jescheck \& Thomas Weigend, Lehrbuch des Strafrechts: Allgemeiner Teil 195 (5th ed. 1996).

${ }^{19}$ Id. Note, however, that the authors also warn of the "danger of a criminal law doctrine that excessively relies on abstract formulas" and "disregards the particularities of the individual case." Id. at 195-96.

${ }^{20}$ See generally Bernd Schünemann, Strafrechtsdogmatik als Wissenschaft, in Festschrift für Claus Roxin zum 70. Geburtstag 1 (Bernd Schünemann et al. eds. 2001).

${ }^{21}$ On the origins of the German idea of legal science, and its influence on nineteenth American jurisprudence, see generally Mathias Reimann, Nineteenth Century German Legal Science, 31 B.C. L. Rev. 837 (1990).

${ }^{22}$ Michael H. Hoeflich, Law \& Geometry: Legal Science from Leibniz to Langdell, 30 Am. J. Legal Hist. 121 (1986); Marcia Speziale, Langdell's Concept of Law as Science: The Beginning of

Anti-formalism in American Legal Theory, 5 Vt. L. Rev. 1 (1980); Howard Schweber, The Science of Legal Science: The Model of the Natural Sciences in Nineteenth-Century American Legal Education, 17 L. \& Hist. Rev. (1999).

23 The German analogue, and precursor, of American Legal Realism, the Free Law School (Freirechtsschule) of the early twentieth century, had no lasting effect on German jurisprudence, in stark contrast to Realism's transformative effect in the United States, which continues to this day, through Realism's contemporary heirs, "Law and Economics" and "Law and Society." In fact, German criminal law bears a certain stylistic resemblance to classical formalism in American law prior to Realism's arrival.
} 
questioned) scientific status of the social and behavioral sciences, economics chief among them, with sociology a remote second. ${ }^{24}$

\section{A. The Role of the Professoriate}

As science, German criminal law is the province of scientists. As criminal law scientists, German professors traditionally have enjoyed significant influence on the doctrine of criminal law, though that influence has begun to fade somewhat over the past few decades. Historically, the significance of the German professoriate has dwarfed that of the German judiciary-and certainly that of Anglo-American legal scholars. It is a commonplace that German law, as the law of all civil law countries, is codified, rather than "judge-made." German judges, as the theory goes, are applying the law, rather than making it, by "subsuming" fact patterns under codified legal norms. This much is true. What's easily forgotten, however, is that the statutory norms the courts are applying to facts, particularly in the general part of criminal law, often do not say very much at all, and that they are, in fact, incomplete by design. The ambiguities and gaps in the code are filled by the professor-scientists, who through continuous scientific research and discourse refine the science that is the criminal law, and whose discoveries aid - or at least should aid - judges in resolving particular cases and, more ambitiously still, the legislature in reforming the criminal code.

The German criminal code thus is remarkably short. It's noteworthy not so much for what it contains, but for what it leaves out. One example is the definition of the various types of mens rea - intention (Vorsatz) and negligence (Fahrlässigkeit). The American Model Penal Code devotes great effort to this task. It would be no exaggeration to say, in fact, that the section defining the four mental states (purpose, knowledge, recklessness, and negligence) is the core of the entire Model Code, and its most important contribution to law reform. ${ }^{25}$ The German criminal code, by contrast, does not define the mental element of crime. Definitions were proposed on the occasion of the basic reform of the general part of the German code in the 1970s. ${ }^{26}$ They were removed, however, for the explicit purpose of leaving their continued refinement to the development of legal science.

Although the influence of the professoriate waned in the late twentieth century, it remains considerable to this day. All German law students are required to take two years of substantive criminal law (one year each on the general and the special part), and at least one year of criminal procedure. These comprehensive courses traditionally have followed a strict lecture format, with the professor often sticking so closely to a prepared script that students' lecture notes are bound and sold to incoming students. The primary

\footnotetext{
${ }^{24}$ Criminal law as a science (Strafrechtswissenschaft) must be distinguished from the attempt to integrate it into a more comprehensive scientific program, which includes other (social) sciences as well. In Germany, this program is generally associated with its early champion, Franz v. Liszt, who in the late nineteenth century gave it the somewhat awkward, but still popular, name "general criminal legal sciences" (gesamte Strafrechtswissenschaften), encompassing both criminal legal science and "criminal sciences," including most importantly criminology.

${ }^{25}$ See Markus D. Dubber, Model Penal Code $§ 4.2$ (2002).

${ }^{26}$ Alternativ-Entwurf eines Strafgesetzbuches: Allgemeiner Teil 56-57 (2d ed. 1969).
} 
teaching tools are not collections of court opinions, but textbooks written by professors and, for more ambitious students, treatises. ${ }^{27}$

Note also that admission to the German bar, or entry into the legal profession, is not policed exclusively by members of the profession, as in the United States. Instead criminal law professors - acting in their capacity as servants of the state - participate in administering the official "state examinations" (Staatsexamen) required for admission to legal practice. ${ }^{28}$

The professoriate's influence on the doctrine of criminal law, however, goes beyond the training, and licensing, of its practitioners. Traditionally, criminal law professors have played an important role in criminal code drafting and reform. The Bavarian Penal Code of 1813, hailed as the first modern German criminal code, was drafted by a professor, Paul Johann Anselm Feuerbach, ${ }^{29}$ who is considered the founder of modern German criminal law. Feuerbach's draft in turn resulted from his criticism of a draft submitted by another professor (by the curious name of Gallus Aloys Kleinschrod). ${ }^{30}$ Professors took part in the fundamental reform of the German criminal code in the 1970s not only directly, through participation in the official parliamentary drafting commission, but also indirectly, through the development and publication of a comprehensive, and influential, "Alternative Draft." 31 Unlike the American Model Penal Code, which was drafted by the American Law Institute from 1952 to 1962 under the direction of Professor Herbert Wechsler of Columbia Law School with the significant contribution of leading judges like Learned Hand, the authors of the Alternative Draft had no institutional affiliation, or backing, beyond their status as criminal legal scientists. ${ }^{32}$

\footnotetext{
${ }^{27}$ Recently law lectures at German universities have become somewhat more interactive and court opinions are beginning to receive more attention in teaching materials as a result of several factors, including the general lowering of professors' status vis-à-vis the student body in the wake of the 1960s student movement, attempts to reform German legal education loosely based on an American model (including the introduction of teaching evaluations), and the growing sense (particularly among the professors themselves) that the professoriate's influence on the judiciary, and the legislature, has diminished. Even some "casebooks" have begun to appear, starting with constitutional law, though they remain very much the exception.

${ }^{28}$ There are two sets of exams, one following the completion of coursework, the other after a subsequent mandatory period of apprenticeship. Professors help administer the first set, which consists of written and oral examinations.

${ }^{29} 1775-1833$. Feuerbach was the father of the important philosopher Ludwig Feuerbach (1804-72), and a colorful figure in his own right. After falling victim to an intrigue at the Bavarian Court, Feuerbach was appointed to a rural judgeship. There he found himself in the unusual position of applying the very code he had drafted. Finding the deterrence-oriented code overly strict and incapable of taking into account the culpability of individual defendants, Feuerbach grew frustrated and recorded his experiences in a series of popular case histories. He also wrote a highly scandalous book about a young man who one day walked into town after claiming to have been raised by wolves. Feuerbach suspected that he was the illegitimate offspring of a local aristocrat. See generally Gustav Radbruch, Paul Johann Anselm Feuerbach: Ein Juristenleben 76 (3d ed. 1969) (1934) (a biography of Feuerbach written by Gustav Radbruch, himself an important German criminal law scholar and justice minister in the Weimar Republic).

$301762-1824$.

${ }^{31}$ Jürgen Baumann et al., Alternative Draft of a Penal Code for the Federal Republic of Germany (Joseph J. Darby trans. 1977).

32 On the significance of the American Law Institute's prestige for the Model Penal Code project, see Markus Dirk Dubber, Penal Panopticon: The Idea of a Modern Model Penal Code, 4 Buffalo Criminal Law Review 53 (2000).
} 
To their great chagrin, the German professoriate had little influence on the recent revision of the code's special part, raising the specter of "Legislation Without Criminal Legal Science." 33 Legislatures' failure to pay sufficient heed to advancements in German criminal legal science has become a common complaint among German criminal law professors. $^{34}$ The fear of irrelevance has spread from domestic law to international law, in particular the development of a system of European criminal law and of an international criminal law, associated with the creation of the International Criminal Court. $^{35}$

Based on a yet longer tradition is the professoriate's participation in the judicial branch of government. Through the latter half of the eighteenth century, and in some German states until the beginning of the nineteenth century, the law faculties of German universities functioned as a kind of expert appellate court. In a famously cumbersome, and time-consuming, procedure known as Aktenversendung, judges would send the professors a sealed case file for their consideration. The faculty would then resolve the case, draft a decision (ratio decidendi), and return it to the judge, who would announce the judgment. This practice has been discontinued for some time, of course. But even today, German law professors may, at their discretion, serve as part-time judges, simply on the strength of their professorial appointment at state universities. ${ }^{36}$

The professoriate's greatest influence on German criminal law, however, has come not through extensive teaching, licensing, legislation, or adjudication, but through the publication of treatises, textbooks, and code commentaries. The doctrinal literature on German criminal law, which has been accumulating since the early nineteenth century, is vast in every respect. Not only does it reach every nook and cranny of doctrine; it creates, or rather discovers, the nooks and crannies in the first place. The comprehensive and complex artifice that is German criminal law is almost entirely a creation of the German professoriate. Even though the influence of the judiciary has increased over the past century, it still cannot match the scope and depth of the professoriate's continuing scientific output. $^{37}$

In the traditional German model of criminal law as science, to the extent that the judiciary participates in the construction of criminal law doctrine, it does so mostly by adopting a particular solution, or approach, favored by a particular academic school. In fact, German judicial opinions in criminal law, of which there are many because every decision in every case must be supported by reasons in writing, read more like expert reports than like opinions of common law courts. They closely follow the tripartite analytic structure of criminal law science, which has remained more or less unchanged

${ }^{33}$ So the title of the 1999 biannual meeting of German criminal law professors (Halle, May 1999) (“Gesetzgebung ohne Strafrechtswissenschaft?").

${ }^{34}$ It has also become a popular conference topic. See, e.g., Krise des Strafrechts und der Kriminalwissenschaften? (Hans Joachim Hirsch ed. 2001).

${ }^{35}$ See, e.g., Cornelius Prittwitz, Nachgeholte Prolegomena zu einem künftigen Corpus Juris Criminalis für Europa, $113 \mathrm{ZStW} 774$ (2002).

${ }^{36}$ There are no private German law schools to speak of.

${ }^{37}$ For instance, the massive "Leipziger Kommentar" on the German criminal code in its most recent complete edition - the 10th-takes up eight volumes and ca. 8,000 pages, published over the course of eleven years. Leipziger Kommentar: Strafgesetzbuch (Hans-Heinrich Jescheck et al. eds. 10th ed. 19781989); see also Adolf Schönke \& Horst Schröder, Strafgesetzbuch (Theodor Lenckner et al. eds. 25th ed. 1997) (ca. 2,390 pp.). 
since it was developed by professors - not the judiciary or the legislature - in the early twentieth century. Generally short on facts, and long on legal rules, these opinions reflect the abstract style traditionally favored by German criminal law science. Judges, it should be noted, are appointed immediately upon graduation from university primarily on the basis of their performance on the state exams. They have no practical legal experience apart from the two-year apprenticeship sandwiched between the first and second set of state exams. Upon appointment, judges are promoted through the ranks from trial to appellate courts based on their performance, as evaluated by their superiors in the judicial hierarchy.

Someone once said that the difference between a court opinion in a civil law system and one in a common law system is that the first is addressed to fellow judges - or rather one's superior judges who make all decisions on personnel matters - and the latter to the public. There is some truth in this observation, except that in the case of German criminal law, the audience includes not only one's judicial superiors, but the professoriate as well.

\section{B. Substance and Procedure}

The absence of a jury, and meaningful lay participation of any kind in the German criminal process, may further contribute to what to an Anglo-American observer appears as the formalism, if not outright obscurity, of German criminal law in general, and criminal court opinions in particular. German criminal law doctrine is literally selfreferential - it is created by experts for experts, be they judicial or professorial. ${ }^{38}$ There is no need to translate complex doctrinal constructs into jury instructions, or into a judgment that a layperson could understand, never mind render herself (as a juror would). The intricacies of German criminal law doctrine in fact serve an important institutional function. They allow professional judges to dominate the few lay participants who remain in the German criminal process today. In the lower courts - not the lowest, which are run by a professional judge sitting along - lay judges outnumber the (presiding) professional judge two-to-one. They could therefore, in theory, exert tremendous influence on decisionmaking. In practice, however, their impact is negligible, thanks in considerable part to the professional judge's expertise in a criminal law doctrine that is not only enormously complex and comprehensive, but also appears - by and large - not in published statutes but in a forbiddingly inaccessible expert literature. ${ }^{39}$

In Anglo-American criminal law, by contrast, a criminal law doctrine is only as good as a jury instruction. And of course the criminal judgment itself is famously oracular - in the absence of special verdicts and a justification, or explanation, of any kind, the jury's verdict of guilty or not guilty makes reference to no doctrine whatsoever. In fact, one of the functions of the American jury has long been its discretion to ignore the apparent

\footnotetext{
${ }^{38}$ And so whatever constraints upon the accessibility of German criminal law doctrine are recognized, even in theory, reflect concerns about its efficient implementation in routinized procedures by expert officials"police, prosecutors, and courts." Hans-Heinrich Jescheck \& Thomas Weigend, Lehrbuch des Strafrechts: Allgemeiner Teil 198 (5th ed. 1996) (goals of clarity and simplicity).

${ }^{39}$ On lay participation in the German criminal process, see Markus Dirk Dubber, American Plea Bargains, German Lay Judges, and the Crisis of Criminal Procedure, 49 Stan. L. Rev. 547 (1997). For an excellent brief summary of German criminal procedure, see Thomas Weigend, Germany, in Criminal Procedure: A Worldwide Study 187 (Craig M. Bradley ed. 1999).
} 
demands of doctrine, and acquit in the teeth of the evidence. (Conviction through jury nullification is supposed to be prevented through the judge's power to acquit non obstante verdicto.)

The absence of the jury, along with a greater penchant for categorical separation, also helps explain the substantiveness of German criminal law, i.e., the comparative insignificance of evidentiary notions such as "affirmative defenses" or "burdens of proof" familiar from Anglo-American criminal law. To begin with, in a criminal process run by professionals, and professional judges in particular, rules of evidence play a less central role than in a process that places the ultimate decision regarding the sufficiency of the evidence in the hands of a group of more or less randomly selected nonexperts, as the contrast between a bench trial and a jury trial in the common law system makes clear. Without a group of impressionable and confusable laypeople, so the argument goes, there is less of a need to carefully limit what evidence is introduced and, once introduced, how it is to be presented, and weighed.

Unlike the common law trial, the German criminal process is based on the assumption that its goal is the discovery of truth by the court. In the inquisitorial model, the judge discharges his duty to find the truth by accumulating whatever evidence he finds most helpful in whatever form he deems most appropriate, and then considers that evidence as he sees fit. ${ }^{40}$ Not only the jury is missing, in other words, so is the adversarial process. The judge is not only the weigher of evidence, but also its presenter.

As a result, evidentiary concerns that drive so much of Anglo-American criminal law - such as the definition of burdens of proof (production and persuasion), the selection of the proper evidentiary burden for a particular issue of concern, and the assignment of burdens of proofs to the parties - are of minor importance in German criminal procedure and of even less importance in German substantive criminal law. There are no affirmative defenses, for instance, no matter of what type (shifting only the burden of production or also the burden of persuasion, shifting the burden of proving the defense beyond a reasonable doubt, by clear and convincing evidence, or merely by a preponderance of the evidence), ${ }^{41}$ nor is there a distinction between burdens of proofs attaching to elements of an offense and those attaching to sentencing considerations, another question that has attracted much interest-and created much confusion-in Anglo-American criminal law. ${ }^{42}$

The latter distinction, between burdens of proofs on matters of liability (or guilt) and matters of sentencing (or punishment), is irrelevant for another, important, procedural reason. Unlike the Anglo-American trial, there is no distinction, institutional or temporal,

\footnotetext{
${ }^{40}$ See, e.g., Claus Roxin, Strafverfahrensrecht 84 (23 ed. 1993) ("the court determines the facts on its own ('instructs' itself) and in this regard is not bound by the motions and declarations of the process participants"). This is not to say, of course, that enterprising criminal defense attorneys-especially in the past few decades-may not make every effort to shape the nature and import of the evidence that the presiding judge decides to collect. See Markus Dirk Dubber, American Plea Bargains, German Lay Judges, and the Crisis of Criminal Procedure, 49 Stan. L. Rev. 547 (1997).

${ }^{41}$ Contrast Model Penal Code $\S 1.12$ (burden of production with N.Y. Penal Law $\S 25.00$ (burden of persuasion); see also Patterson v. New York, 432 U.S. 197 (1977) (preponderance of the evidence); Leland v. Oregon, 343 U.S. 790 (1952) (beyond a reasonable doubt).

${ }^{42}$ See most recently Apprendi v. New Jersey, 530 U.S. 466 (2000).
} 
between the guilt and sentencing phases of the criminal process. The court decides both questions, and both questions at once, or rather seriatim during the same deliberation.

At bottom, the irrelevance of evidentiary matters in German substantive criminal law reflects a different relationship between substance and procedure. In Anglo-American law criminal procedure traditionally has attracted the lion's share of doctrinal attention. Nothing illustrates the primacy of procedure in Anglo-American criminal law - as well as of course the adversariness of that procedure - than the basic conceptual framework of substantive criminal law, which divides the field of inquiry into "offenses" and "defenses." The heart of substantive German criminal law, by contrast, is its "general theory of crime" which lays out the "general legal prerequisites of punishability." "43

In German criminal law, substance takes priority over procedure. Substantive criminal law concerns itself with the legal principles that are then, subsequently, applied in the criminal process. How these principles are applied, or by whom, is irrelevant for purposes of determining what they are, or should be. Considerations of evidentiary convenience, for instance, are therefore by definition out of place in discussions of substantive criminal law. ${ }^{44}$

\section{Scientific Progress}

The German science of criminal law-much like the German criminal trial-seeks truth, ultimately, or rightness. Doctrines of criminal law, for that reason, are not simply developed, or refined, or adapted, they are "discovered." The history of German criminal law theory is a history of these discoveries. ${ }^{45}$

This spirit of scientific discovery, and the concomitant deep commitment to truth, means, that at bottom German criminal law is not just about German criminal law, but about criminal law, period. ${ }^{46}$ It is a science of the nature of crime and punishment, nothing less. In fact, more or less explicitly ontological or phenomenological claims based on an understanding of "the nature of the thing" (die Natur der Sache) are not

\footnotetext{
${ }^{43}$ Hans-Heinrich Jescheck \& Thomas Weigend, Lehrbuch des Strafrechts: Allgemeiner Teil 194 (5th ed. 1996).

${ }^{44}$ See, e.g., Hans Joachim Hirsch, Tatstrafrecht—ein hinreichend beachtetes Grundprinzip?, in Festschrift für Klaus Lüderssen 253, 260 (Cornelius Prittwitz et al. eds. 2002).

${ }^{45}$ See, e.g., Claus Roxin, Strafrecht: Allgemeiner Teil I, at 149-50 (3d ed. 1997) (charting "the discovery of the fundamental concepts" of criminal law and "their adoption by the legislature"). As one example, consider the "discovery" of "normative" and "subjective" offense elements like the animus furandi of theft. Hans-Heinrich Jescheck \& Thomas Weigend, Lehrbuch des Strafrechts: Allgemeiner Teil 185, 206 (5th ed. 1996); Claus Roxin, Strafrecht: Allgemeiner Teil I, at 229 (3d ed. 1997); Johannes Wessels, Strafrecht: Allgemeiner Teil 34 (23d ed. 1993). The discovery here was not the animus furandi itself, of course, but its doctrinal classification as an offense element, rather than as an issue relating to guilt: without animus furandi, it was discovered, no theft had been committed in the first place, rather than, as previously thought, a theft had been committed, but guilt was lacking. The defendant would be acquitted either way.

${ }^{46}$ This commitment to scientific progress also translates into a surprisingly ahistorical attitude to criminal law; every scientific advance, after all, means the abandonment of a previously held hypothesis, which has turned out to be false. Earlier theories are of interest only to the extent they have withstood the test of time. For a rare study of the historical development of some of the basic concepts of German criminal law, see Bernd Schünemann, Einführung in das strafrechtliche Systemdenken, in Grundfragen des modernen Strafrechtssystems 1 (Bernd Schünemann ed. 1984).
} 
uncommon. $^{47}$ "Finalism," easily the most influential recent theory of German criminal law, developed an entire system of criminal liability based on an appreciation of the "ontological structure" of conduct (Handlung), with the aim of placing it on a "foundation of the law of being," 48 as revealed by discoveries of "the newer psychology regarding the translation of psychic acts into the external world." 49 Even the more levelheaded, and methodologically self-conscious, among commentators view themselves as exploring the implications of "concrete-general concepts" within the constraints of a "thing logic" (Sachlogik), as opposed to deriving their entire system from the "nature of the thing," as the finalists claim to do. ${ }^{50}$

A much discussed recent attempt at system building explicitly sets out to move beyond the "ontologizing" habits of traditional criminal law theory, and of finalism in particular. ${ }^{51}$ Closely associated with Günther Jakobs, a student of the founder of finalism, Hans Welzel, it instead works out another discovery of Welzel's, this one regarding the function of criminal law: "to secure the recognition of positive socio-ethical act-values." 52 This "functionalist" (or "normative") theory is indeed refreshingly free of confident pronouncements about the nature of things. Functionalism, however, appears to have replaced the ontological obscurantism of finalism with an obscurantism derived from its very own grand theory $d u$ jour - systems theory.

At the outset, functionalism stood for little more than the recognition that the doctrine of criminal law should take into account the purposes, or functions, of punishments. This was considered a significant departure from tradition because it suggested that criminal legal science might do more than ponder the essence of ontological reality - say, of human conduct, causation, or "thing-logical structures." 33 Remarkably this discovery was not made until 1970 in a famous programmatic monograph entitled "Criminal Policy and Criminal Law System." 54 The idea that the doctrine of criminal law - that great construct of criminal legal science - might reflect, even in part, some theory of punishment or other (the prime example is the almost universally favored theory, "positive general prevention" according to which the punishment serves "to establish to the legal community the inviolability of the legal order and thereby to strengthen the

\footnotetext{
${ }^{47}$ Hans-Heinrich Jescheck \& Thomas Weigend, Lehrbuch des Strafrechts: Allgemeiner Teil 210-11 (5th ed. 1996) (finalism).

${ }^{48}$ Claus Roxin, Strafrecht: Allgemeiner Teil I, at 189 (3d ed. 1997) (discussing Welzel).

${ }^{49}$ Hans-Heinrich Jescheck \& Thomas Weigend, Lehrbuch des Strafrechts: Allgemeiner Teil 211 (5th ed. 1996) (finalism). Finalism takes its name from what its adherents call the "finalist" (or intentionalist) concept of act (finale Handlungsbegriff). In their view, the finality of an act derives from the fact that "man can due to his causal knowledge foresee the possible results of his actions and, for that reason, set himself various aims and direct his actions toward their accomplishment." Claus Roxin, Strafrecht: Allgemeiner Teil I, at 188-89 (3d ed. 1997). Only quite recently was it pointed out that this view of a criminal act cannot account for crimes of omission or of negligence. Id. at 190-91.

${ }^{50}$ Claus Roxin, Strafrecht: Allgemeiner Teil I, at 180-81 (3d ed. 1997). Invocations of "the sense of justice" in support of a claim are perhaps less forbiddingly obscure, but no less unhelpful, and no less uncommon. Hans-Heinrich Jescheck \& Thomas Weigend, Lehrbuch des Strafrechts: Allgemeiner Teil 463 (mistake regarding justification), 604 (omission vs. commission) (5th ed. 1996) ("Rechtsgefühl" (sense of right)); Claus Roxin, Strafrecht: Allgemeiner Teil I, at 60 (3d ed. 1997) ("Gerechtigkeitsgefühl" (sense of justice) demands punishment according to desert).

${ }_{51}$ Günther Jakobs, Strafrecht: Allgemeiner Teil vii (2d ed. 1991).

${ }^{52}$ Id. (quoting Hans Welzel, Das Deutsche Strafrecht: Eine systematische Darstellung 2 (11th ed. 1969))

${ }^{53}$ Claus Roxin, Strafrecht: Allgemeiner Teil I, at 155 (3d ed. 1997).

${ }^{54}$ Claus Roxin, Kriminalpolitik und Strafrechtssystem (1970).
} 
populace's loyalty to the law"55), which itself would be subject to public political debate was considered a grave threat to the project of criminal legal science itself, for it abandoned its natural, and privileged, foundation.

The recent rediscovery of Kant and Hegel (and, to a lesser extent, Fichte) is likewise noteworthy, for it suggests, if nothing else, that Kant and Hegel needed rediscovering. ${ }^{56}$ This may come as a surprise to an Anglo-American observer given the widely shared assumption that modern criminal law theory, and certainly modern German criminal law theory, rests on a Kantian, and less clearly also a Hegelian, foundation. Kant's and Hegel's influence on German criminal law theory, however, has been surprisingly limited. $^{57}$ No self-consciously Kantian school of criminal law ever developed in the nineteenth century. Feuerbach may have considered himself a Kantian, but only in the general sense that he followed Kant in insisting on a strict separation of legality and morality. Unlike Kant, Feuerbach was not a retributivist, but a strict adherent of general deterrence. $^{58}$ The nineteenth century did produce several Hegelian scholars of criminal law. ${ }^{59}$ Their influence on the doctrine of criminal law, however, was limited, partly because Hegelianism ran its course in all aspects of German intellectual life, partly because whatever influence they did have preceded the enactment of the German Criminal Code in 1871, which through the unification of the various German states ended the particularism of German jurisprudence and marked the beginning of the construction of a German criminal law science in earnest.

More generally, there is a certain reticence to ground criminal law science on a foundation thought to be external to criminal law science itself-despite the fact that finalism and functionalism draw inspiration from early twentieth-century ontology and

\footnotetext{
${ }_{55}^{55}$ Positive general prevention is discussed in detail in pt. II.

56 See, e.g., Michael Köhler, Strafrecht: Allgemeiner Teil (1997); Michael Köhler, Freiheitliches Rechtsprinzip und Betäubungsmittelstrafrecht, 104 ZStW 3 (1992); Ernst Amadeus Wolff, Das neuere Verständnis von Generalprävention und seine Tauglichkeit für eine Antwort auf Kriminalität, 97 ZStW 786 (1985); Diethelm Klesczewski, Die Rolle der Strafe in Hegels Theorie der bürgerlichen Gesellschaft (1991); Rainer Zaczyk: Das Strafrecht in der Rechtslehre J.G. Fichtes (1981). Jakobs too recently has taken to invoking Hegel's legacy. See Günther Jakobs, Das Strafrecht zwischen Funktionalismus und "alteuropäischem” Prinzipiendenken, 107 ZStW 843 (1995); Günther Jakobs, Norm, Person, Gesellschaft: Vorüberlegungen zu einer Rechtsphilosophie (1997).

57 The much-cited essay by Ulrich Klug, entitled "Farewell to Kant and Hegel," is not to the contrary. Ulrich Klug, Abschied von Kant und Hegel, in Programm für ein neues Strafgesetzbuch: Der AlternativEntwurf der Strafrechtslehrer 36 (Jürgen Baumann ed. 1968). This five-page essay provides a critical, and rather superficial, discussion of Kant's and Hegel's writings on crime and punishment. It does not even pretend to expose, never mind to dismantle, the Kantian or Hegelian underpinnings of current German criminal law. Instead, published in 1968 in a collection of essays dedicated to the alternative draft of a German criminal code prepared by a group of progressive law professors, it provides some historical background to the common call for recodification along rehabilitative, rather than retributivist or "metaphysical," lines. To the extent it is attacking current Kantian and Hegelian criminal law doctrine, it is attacking a straw man.

${ }^{58}$ On Feuerbach's limited Kantianism, see Wolfgang Naucke, Kant und die psychologische Zwangstheorie Feuerbachs (1962). This unwavering commitment to general deterrence led Feuerbach, for instance, to increase-rather than mitigate-punishment in cases of duress, so as to counterbalance the increased incentive for criminal conduct represented by the source of the duress (be it economic, circumstantial, or personal). And it was also the reason that Feuerbach in his judicial capacity found the application of his Bavarian criminal code in actual cases so distasteful.

${ }^{59}$ Prominent Hegelians among German criminal law scholars include Julius Abegg (1796-1868), Reinhold Köstlin (1813-1856), Hugo Hälschner (1817-1889), and Albert Friedrich Berner (1818-1907).
} 
late-twentieth century systems theory. ${ }^{60}$ There is, for instance, little connection between German criminal law science and contemporary political theory. There is no Habermasian theory of punishment ${ }^{61}$ nor is there any noticeable effort to translate whatever that theory would be into a concrete criminal law doctrine. The work of other contemporary political theorists, such as John Rawls, has likewise attracted little interest among German criminal legal scientists. ${ }^{62}$

Relatedly German criminal law theory has defended its scientific independence even from other subdisciplines within the science of law. Criminal law has maintained a careful distance to public law, despite the fact that criminal law is clearly a variety of public law in that it governs a particular form of legal interaction between the state and its citizens (punishment), rather than the legal relationship among private individuals, as in the case of private law.

More recently, German criminal law science has struggled to accommodate another, more fundamental, variety of public law: constitutional law. ${ }^{63}$ Insofar as it thinks of itself as based upon ontological facts about the world, criminal law science exists independently from, and logically precedes, constitutional law. The structure of criminal liability, discovered in the early decades of the twentieth century, is a matter of (ontological) fact regardless of what the constitution might say, or even of whether there is any constitution at all. German criminal legal science, after all, is seen as having followed a single trajectory of scientific progress, moving from discovery to discovery, and presumably closer to truth, during the German Empire, during the Weimar Republic, during the Nazi period, and since then. Modern German constitutional law, however, did not even come into being until 1949, with the passage of the Basic Law.

The concern with the autonomy of German criminal legal science, not only from other disciplines within and outside law and from anything resembling "policy," may well reflect considerable unease regarding the role of German criminal law, and its professorial and judicial practitioners, under the Nazi regime. Some of the central features of German criminal law - such as the famed two-track system of punishments and penal measures - stem from the Nazi period. (The two-track system was enacted in

\footnotetext{
${ }^{60}$ That is not to say that some German criminal law scholars have not made significant efforts to break out of what they perceived to be the isolation of their discipline by, for instance, opening up a dialogue with the social sciences. See, e.g., Vom Nutzen und Nachteil der Sozialwissenschaften für das Strafrecht (Klaus Lüderssen \& Fritz Sack eds., 2 vols. 1980) ("On the Benefits and Detriments of the Social Science for Criminal Law"). For a recent critical assessment of work in this vein, see Ernst-Joachim Lampe, Strafrechtsdogmatik und Sozialwissenschaften, in Festschrift für Klaus Lüderssen 279 (Cornelius Prittwitz et al. eds. 2002)

${ }^{61}$ With the exception of a suggestive essay by Klaus Günther. Klaus Günther, Möglichkeiten einer diskursethischen Begründung des Strafrechts, in Recht und Moral: Beiträge zu einer Standortbestimmung 205 (Heike Jung, Heinz Müller-Dietz \& Ulfrid Neumann, eds., 1991). Much of Günther's work, in fact, has been dedicated to bridging the gap between criminal law and political theory identified in the text.

${ }^{62}$ For an overview of Rawls's remarks on punishment in A Theory of Justice, see Jutta Wittig, Die Aufrechterhaltung gesellschaftlicher Stabilität bei John Rawls, 107 ZStW 251 (1995).

${ }^{63}$ There are some notable exceptions to this rule, chief among them Claus Roxin. See Claus Roxin, Strafrecht: Allgemeiner Teil I, at 15-17 (3d ed. 1997) (constitutional foundation of Rechtsgut); see also infra ch. 2. Even those who, like Roxin, stress the need to turn to constitutional law, however, generally stop well short of establishing, as opposed to asserting, a constitutional foundation for the well-established principles of German criminal law. See generally Ivo Appel, Verfassung und Strafe: Zu den verfassungsrechtlichen Grenzen staatlichen Strafen (1998).
} 
1933, shortly after the Nazis came to power. ${ }^{64}$ ) The same is true of several of the major discoveries of German criminal legal science. Welzel, for instance, worked out the basics of finalism in the 1930s, culminating in a still much-cited article in 1939, and the first edition of his influential textbook in $1940 .{ }^{65}$ Other legislative and doctrinal innovations did not survive past 1945, chief among them the legislative recognition of punishment by analogy - i.e., despite the absence of a specifically applicable statutory prohibition - in $1935,{ }^{66}$ a reform that found wide scholarly support at the time, including among some professors who continued to play an important role in German criminal legal science after $1945 .^{67}$

Scholars steeped in the view of criminal law as science might well read the decidedly mixed record of German criminal legal science during the Nazi period both as confirmation of the scientific nature of his endeavor (since many "discoveries" were made nonetheless) and as a warning to those who dare to mix science with "criminal policy" (since many criminal law scholars strayed off the path of science and committed errors as a result). It's no surprise, then, that the initial appearance of modest "functionalism" in the 1970s coincided with the rise of a new generation of German criminal law scholars who were not active during the Nazi period.

\section{Criminal Law as Taxonomy}

A natural science to which German criminal legal science might be fruitfully compared is botany, or zoology. ${ }^{68}$ Much of German criminal law theory is devoted to classification. Once the basic impetus for classification has been provided, often by the kind of insight into the order of things just mentioned, the German criminal legal scientist seeks to assign each element of the doctrine its proper place in the classificatory system of the criminal law.

This classificatory approach to criminal law science has three main effects. First, it furthers the goals of internal consistency and comprehensiveness. Whatever the

\footnotetext{
${ }^{64}$ Law against dangerous recidivists and regarding measures of protection and rehabilitation (Gesetz gegen gefährliche Gewohnheitsverbrecher und über Maßregeln der Sicherung und Besserung), Nov. 24, 1933. For more on the two-track system, see text accompanying notes __- _ infra.

${ }^{65}$ Hans Welzel, Studien zum System des Strafrechts, 58 ZStW 491 (1939); Hans Welzel, Der Allgemeine Teil des deutschen Strafrechts in seinen Grundzügen (1st ed. 1940). But see Hans-Heinrich Jescheck, Lehrbuch des Strafrechts: Allgemeiner Teil 179 (4th ed. 1988) ( "political attitude" had no influence on criminal law theory during Nazi period in general (with one possible exception), and on finalism in particular).

${ }^{66}$ Law to amend the Criminal Code (Gesetz zur Änderung des Strafgesetzbuchs), June 28, 1935.

${ }^{67}$ See, e.g., Friedrich Schaffstein's 1934 book, entitled provocatively Political [!] Criminal Legal Science (Politische Strafrechtswissenschaft); see generally Gerhard Wolf, Befreiung des Strafrechts vom nationalsozialistischen Denken?, 1996 JuS 189; Markus Dirk Dubber, Judicial Positivism and Hitler's Injustice, 93 Colum. L. Rev. 1807 (1993) (reviewing Ingo Müller, Hitler's Justice: The Courts of the Third Reich (1991)). For a recent overview of Nazi ideas on German criminal law, see Joachim Vogel, Einflüsse des Nationalsozialismus auf das Strafrecht, 115 ZStW 638 (2003).

${ }^{68}$ The aforementioned discoveries of German criminal legal science thus would be analogous to the discovery of a new plant, or perhaps even of a new entirely new species of plants. For an interesting discussion of the very explicit connection between "taxonomical sciences," such as botany and zoology, and nineteenth century American legal science à la Langdell, see Howard Schweber, The "Science" of Legal Science: The Model of the Natural Sciences in Nineteenth-Century American Legal Education, 17 Law \& Hist. Rev. 421 (1999).
} 
advantages of the case-based, fact-centered, judge-dominated approach to legal issues characteristic of the common law might be, systematic scope is not among them. German criminal law science is not fact-, but concept-driven. Even court opinions can display a certain impatience with statements of fact. ${ }^{69}$ A cursory rendition of the facts makes room for a more expansive consideration of the issue at hand within the context of the criminal law system as a whole. Rather than a particular "case or controversy" before the court, it is some doctrinal problem that awaits resolution.

Second, the power of taxonomy provides its practitioners with a potent, and handy, rhetorical tool. For classification implies the possibility of misclassification. No "mistake" is more common in German criminal law opinions - and criminal law exams than a category mistake, at least according to the taxonomy's main keepers, and authors, the criminal law professors. Still, when confronted with the occasionally dogmatic tone of German criminal law commentary it helps to keep in mind that no matter how categorical the assertion, someone somewhere is likely to make a similarly categorical assertion of the exact opposite. This categorical denial of categoricalness transforms the German science of criminal law into a constant struggle among opposing factions or schools, each of which claims access to scientific truth. The debates among these doctrinal schools are often fought with great gusto and over great spans of time, as the followers of each camp are unlikely to switch sides during their scholarly lifetime. These camps tend to be defined, and controlled, by great charismatic figures - like the paterfamilias of progressivism, Franz v. Liszt, or Welzel, the father of finalism - whose influence emanates through their loyal following composed of former students. ${ }^{70}$

Third, and most significant, the taxonomical mode of German criminal law lends itself to a certain formalism. Arguments are not infrequently resolved by definition, or rather by classification. Once an issue has been properly classified, it has been properly resolved. Given the care with which it has been assembled, and continues to be maintained, it is perhaps not surprising that the classificatory system of German criminal law is asked to do considerable rhetorical work. If the categories are correct, and an issue has been correctly categorized, then the issue has been correctly resolved, or so the

\footnotetext{
${ }^{69}$ The persons constituting the case before the court are referred to by initial only - so that $\mathrm{H}$ solicits B, who then proceeds to stab L in the back, and so on - and judicial opinions as a rule are not identified by the name of the defendant, but by some moniker - such as the "Sirius case" or the "Cat king case" - if not simply by a citation to an official or unofficial case report - such as "BGHSt 32, 38" or "NJW 2001, 2732."

${ }^{70}$ The multitude of solutions proposed for virtually every problem of German criminal law makes it difficult, in fact, to get a handle on just what counts as "German criminal law," rather than this or that approach to it. Not coincidentally, a classification system has been developed to address this problem. When discussing a particular rule, the author-professor or judge—ordinarily will categorize it according to (his perception of) the breadth of support it enjoys in the relevant community, or more precisely the relevant communities, of professors, of judges, or of both together. Beginning with professors, the designation of a rule as "dominant teaching" (herrschende Lehre, or simply h.L.) marks it as endorsed by a majority of scholars. What Anglo-American lawyers would call the majority rule, i.e., the rule endorsed by a majority of courts, is designated "dominant jurisprudence," or "dominant practice" (herrschende Rechtsprechung (Praxis)). A rule supported by the combined community of scholars and judges is referred to "dominant opinion" (herrschende Meinung, h.M.), or "general opinion" (allgemeine Meinung, allg.M.). Adding the adjective "absolut" to any of these markers lends emphasis, and suggests supermajoritarian support, adding "einhellig" implies consensus. By contrast, minority opinions are designated, literally, as "deviant" (abweichend). Alternatively minority positions might be labelled (particularly by their supporters, or perhaps by alarmed opponents) not as deviant, but as "on the rise" ("im Vordringen begriffen").
} 
syllogism goes. In other words, the time that common criminal lawyers spend on fretting over the proper resolution of a particular case, German criminal lawyers instead dedicate to the correct construction of a system for the resolution of all cases. The more effort goes into the building and quality control of the juridical apparatus, the less effort need go into output control. And so indefinite preventive detention, for instance, is legitimate because it is classified not as a "punishment," but as a "measure," and fines of up to one million marks against corporations are legitimate because they are classified as "monetary fines" (or, once again, as a "measure") for "order violations" rather than as "punishments" for "crimes," and so on. ${ }^{71}$

The danger of this taxonomical formalism is, of course, that it may deflect attention from the search for justification, and ultimately legitimation. If the task of the criminal law scientist consists exclusively of identifying - and then filling-gaps within the entirely autonomous system of criminal law, the scientific achievements of German criminal law will be appreciated only by fellow practitioners. Outside observersincluding legislators, the public, and even Anglo-American criminal law scholars-may find themselves mystified and, ultimately, unconvinced.

Now that we have a general sense its basic modus operandi, it is time to take a closer look at the science of German criminal law at work. We will focus on two of its central discoveries, the punishment theory of positive general prevention and the Rechtsgut theory of criminalization.

\section{Positive General Prevention: The Theory of Punishment}

In the Anglo-American literature, the debate about the purpose, or purposes, of punishment largely remains within the familiar framework of consequentialist and deontological theories of punishment. Ordinarily, lists of the purposes of punishment include the following four: deterrence (general and special), incapacitation, rehabilitation (or reformation), and retribution (or just deserts), with the first three classified as consequentialist and the fourth as deontological. The "consequences" that the first seek to achieve might differ from account to account, but the prevention of crime, or reduction of the crime rate, is certain to be among them.

After roughly two centuries of hostilities between the consequentialist and deontological camps, general exhaustion has set in. By and large, punishment theorists and legislatures as well as sentencing commissions - have settled on some "mixed

\footnotetext{
${ }^{71}$ See generally Hans-Heinrich Jescheck \& Thomas Weigend, Lehrbuch des Strafrechts: Allgemeiner Teil 228 (5th ed. 1996) ("fines" (Ordnungsstrafen)); Claus Roxin, Strafrecht: Allgemeiner Teil I, at 209 (3d ed. 1997) ("measures"). See also Günther Jakobs, Strafbarkeit juristischer Personene, in Festschrift für Klaus Lüderssen 560, 574 (Cornelius Prittwitz et al. eds. 2002) (corporate "sanctions" are justifiable as long as they are "not christened with the name "punishment"). Order violations (Ordnungswidrigkeiten) are governed by, and defined in, the Code of Order Violations (OWiG), not the Criminal Code (StGB). Note that the OWiG did not come into being until 1952. Until then, the bulk of offenses now classified as order violations were defined in the StGB as transgressions (Übertretungen), a category of crimes besides felonies and misdemeanors (Verbrechen, Vergehen). Transgressions remained in the StGB until 1968, when traffic offenses were reclassified as order violations. See Hans-Heinrich Jescheck \& Thomas Weigend, Lehrbuch des Strafrechts: Allgemeiner Teil 57-58 (5th ed. 1996).
} 
theory" or other, generously combining elements of what once were thought to be deeply irreconcilable views. $^{72}$

The analytic work of the English legal philosopher H.L.A. Hart proved to be particularly helpful in this regard. By helpfully differentiating between the different questions that a theory of punishment should answer, Hart made different answers to these questions possible. ${ }^{73}$ So one might be a consequentialist with respect to the justification of the institution of punishment in general, while choosing retributivism when it comes to justifying the infliction of punishment in a particular case. More specifically, we might think that we need punishment to deter people from committing crimes, but at the same time that we shouldn't punish people unless they in fact deserve it.

Given the widely acknowledged staleness of debates about the rationales for punishment in Anglo-American law, one might be tempted to turn to the German literature on the subject. And indeed, it turns out that German criminal law theory has made a conscious effort to break out of the consequentialist-deontological rut. Whether the effort succeeds remains to be seen.

\section{A. The Schulenstreit}

German criminal law, too, once witnessed intense battles pitting consequentialists against deontologists, those who proposed punishment ne peccetur against those who preferred punishing quia peccatum est. The fiercest, and most prolonged, period of this dispute even had its own name, the "Clash of the Schools" (Schulenstreit), whose main protagonists were Franz v. Liszt, the founder of German criminology, for the "progressive school," and Karl Binding, the originator of "norm theory" in German criminal law, for the "classical school."

To characterize the dispute between Liszt and Binding (and their associates and successors) as one between consequentialism and retributivism, however, could be misleading. It's important to keep in mind that both Liszt and Binding were thoroughgoing legal positivists. Binding argued that punishment was justified, and only justified, as the state's response to a violation of a state norm. The essence of crime thus was the violation of a norm of positive law, rather than the commission of a wrongful act. The criminal law was not so much a demand of justice, or as Kant would have it, a "categorical imperative," as a state tool for the enforcement of state authority that the state may or may not choose to employ.

The "right to punishment," to Binding, was "nothing but the right to obedience of the law, which has been transformed by the offender's disobedience."74 The purpose of punishment thus was "the inmate's subjugation under the power of law for the sake of

\footnotetext{
${ }^{72}$ See, e.g., United States Sentencing Guidelines ch. 1, pt. A(3) ("resolv[ing] philosophical dilemma" between retributivism and consequentialism by not "accord[ing] one primacy over the other"); 18 U.S.C. $\S$ 3553(a)(2) (deterrence, incapacitation, retribution, rehabilitation).

${ }^{73}$ H.L.A. Hart, Prolegomenon to the Principles of Punishment, in Punishment and Responsibility 1 (1968); see also John Rawls, Two Concepts of Rules, 64 Phil. Rev. 3 (1955); Warren Quinn, The Right to Threaten and the Right to Punish, 14 Phil. \& Pub. Affairs 327 (1985).

${ }_{74}$ Karl Binding, Das Problem der Strafe in der heutigen Wissenschaft, in 1 Strafrechtliche und strafprozessuale Abhandlungen 61, 84 (1915).
} 
maintaining the authority of the laws violated." the holiness and inviolability of the duties to which it is attached.",76

Liszt, by contrast, accused Binding and his fellow classicists of advocating pointless punishment. (That's not quite fair, as we just saw, since Binding thought punishment served the purpose of maintaining state authority.) Liszt insisted that punishment, to be legitimate in a modern enlightened state, had to serve some purpose. Punishment could never be an end in itself. More specifically, Liszt argued that punishment must (and does) seek to protect legal goods (Rechtsgüter) against criminal violation. ${ }^{77}$ These legal goods, in Liszt's view, included, broadly speaking, "the life conditions" of a given community so that crimes were all "those acts that this people at this time perceives as disturbances of its life conditions." ${ }^{\text {, }}$ Punishment served its purpose through rehabilitation (education), deterrence, or incapacitation, depending on the type of offender. The recidivist, for instance, would upon his third conviction of an offense motivated by "the strongest and most basic human drives" (including theft, robbery, arson, and rape, but also damaging property) be sentenced to an indeterminate prison term, to be served in a state of "penal servitude," with the use of corporal punishment to enforce prison discipline. ${ }^{79}$ Truly incorrigible offenders were to be imprisoned for life, because "we do not wish to behead or hang and cannot deport" them - why that would be so Liszt didn't explain. ${ }^{80}$

In keeping with their broadly treatmentist approach, Liszt and his fellow progressives called for more or less radical legislative reforms. ${ }^{81}$ The cumbersome, and legalistic, construct of criminal law doctrine was to be replaced by a more flexible, modern, scientific ("progressive") system for the proper diagnosis, and classification, of offenders, which was crucial for the prescription of the correction quality and quantity of penocorrectional treatment. Ironically these reform proposals did not come to fruition until after the Nazis took power in 1933. One of the Nazis' first criminal law reforms was the Law Against Dangerous Recidivists and Regarding Measures of Protection and Rehabilitation of November 1933, ${ }^{82}$ which established the "two-track" sanctioning system that remains in place today. ${ }^{83}$ Since then, two general types of sanction have been available: punishments and measures. Only punishments "properly speaking" are subject to constraints of proportionality between culpability and sanction. "Measures" instead are unrelated to culpability and are determined exclusively by the offender's penocorrectional diagnosis. So if she requires rehabilitative treatment, she might be sent to a drug rehabilitation clinic; if she requires incapacitative treatment, she might be incarcerated indefinitely. Freed of the constraints of proportionality between offense and

\footnotetext{
${ }^{75}$ Id. at 86.

${ }^{76}$ Id. at 85 .

${ }^{77}$ Franz von Liszt, Der Zweckgedanke im Strafrecht, in 3 ZStW 1, 33-34 (1883) (“Marburg Program”). For more on the concept of Rechtsgut, see ch. __ supra.

${ }^{78}$ Franz von Liszt, Der Zweckgedanke im Strafrecht, in 3 ZStW 1, 23 (1883).

${ }^{79}$ Id. at 40.

${ }^{80}$ Id. at 39.

${ }^{81}$ For treatmentism in early twentieth century American criminal law, and particularly in the Model Penal Code, see Markus Dirk Dubber, Penal Panopticon: The Idea of a Modern Model Penal Code, 4 Buffalo Criminal Law Review 53 (2000).

${ }^{82}$ Law against dangerous recidivists and regarding measures of protection and rehabilitation (Gesetz gegen gefährliche Gewohnheitsverbrecher und über Maßregeln der Sicherung und Besserung), Nov. $24,1933$.

83 The two-track system is discussed in greater detail in ch. __ infra.
} 
sanction, "measures" are served independently - and where appropriate consecutively to whatever "punishments" are imposed.

At the same time, the retention of the distinction between punishments and measures indicates that the victory of the progressive treatmentists was not complete. While "progressive" considerations governed the realm of "measures," that of "punishments" remained subject to "classical" quia peccatum considerations. In the end, then, a statutory compromise was reached. Strafrecht (literally, the law of punishment) remained, but was now only one component of the comprehensive vision of Kriminalrecht (literally, criminal law), which encompassed both punishment and treatment.

\section{B. Positive General Prevention}

The German theory of punishment thus combined once incommensurable deontological and consequentialist elements, much like Anglo-American punishment theory. Unlike Anglo-American punishment theory, however, which has been content to resolve the tension between deontology and consequentialism, and between utilitarianism and retributivism, by combining these ingredients in "mixed" theories, German punishment theory eventually produced an altogether new theory of punishment that aims to reconcile the differences between what the Germans call "relative" and "absolute" theories of punishment.

This is the theory of "positive general prevention" (positive Generalprävention, or PGP for short ${ }^{84}$ ), which today is the dominant theory of punishment in German criminal law. There are many varieties of positive general prevention, so many in fact that discussions of the theory as a matter of course caution that it may well be misleading to speak of the theory, rather than theories, of positive general prevention. Still, the basic features of positive general prevention can be discerned easily enough. It's "general" to distinguish itself from special prevention, which uses punishment to prevent crime by the particular offender subject to punishment, rather than by others. It's also "positive" because it seeks to prevent crime not by scaring potential lawbreakers into compliance, but by bolstering the lawabidingness of the rest of the population. Finally, and relatedly, it's about "prevention" generally speaking, rather than "deterrence" as a particular means of prevention. There could be no such thing as positive deterrence, after all.

It's pretty clear, therefore, what positive general prevention is not. One might think of it, in fact, as being constructed specifically to take advantage of the consensus that special deterrence is an entirely inappropriate attempt to legitimate punishment. Positive general prevention clearly is not negative special prevention (or special deterrence for short). That theory, after all, is generally thought to have been thoroughly, and permanently, laid to rest by the father of modern German criminal law, P.J.A. Feuerbach, at the turn of the nineteenth century. ${ }^{85}$

\footnotetext{
${ }^{84}$ See Winfried Hassemer, Variationen der positiven Generalprävention, in Positive Generalprävention: Kritische Analyses im deutsch-englischen Dialog 29, 43 (Bernd Schünemann et al. eds. 1998).

${ }^{85}$ Feuerbach's argument was largely conceptual, if not to say formalistic. He charged that the special preventionists of his day could not "deduce" a right to "punishment" for past violations, but at best a right to "defense" against future ones. Paul Johann Anselm von Feuerbach, Revision der Grundsätze und Grundbegriffe des positiven peinlichen Rechts pt. 1, at 21 (Erfurt 1799) (reprint Scientia: Aalen 1966); see
} 
But positive general prevention is also not positive special prevention, or rehabilitation. It's no accident that positive general prevention arose out of another, much later and somewhat narrower, consensus in German criminal legal science, namely that - to quote the familiar American phrase - "nothing works." While American criminal law, in particular, responded to the perceived failure of rehabilitative measures by (re)turning to retributivism, or "just deserts" as it was now called, the German response shifted emphasis among the objects of prevention, rather than leaving the realm of consequentialist punishment altogether. If positive special prevention didn't work, then perhaps positive general prevention might. If punishment can't rehabilitate offenders, perhaps it could stiffen the resolve of non-offenders not to become (unrehabilitatable) offenders.

More generally, positive general prevention was hoped to steer clear of the normative and empirical problems that had plagued consequentialist theories of punishment, without endorsing a retributive theory of punishment for its own sake, which was dismissed as literally pointless, and hence barbaric.

The normative problems with deterrence theory have been familiar at least since Kant. The categorical imperative, after all, instructs us never to treat a person merely as a means to an end. And what is punishing one person to deter another from committing a crime, if not treating him as a means to the end of crime control? Invoking Kant in support of positive general prevention, however, is not without irony. Kant, after all, was an arch retributivist, and therefore was very much passé. Moreover, Kant's objection was not limited to deterrence, special or general, but applied to any consequentialist theory of punishment. For what is punishing one person to prevent another from committing a crime - no matter how - if not treating him as a means to the end of crime prevention? ${ }^{86}$

But there was another normative problem with deterrence theories in particular, which a preventive theory, and more specifically a positive one, might avoid. This objection was formulated by another famous German retributivist, Hegel, who argued that prevention through deterrence was illegitimate because it disrespected the dignity of the deterred. For what, Hegel asked, is punishing for deterrence's sake if not treating the intended audience of this spectacle as animals, dogs to be precise, which (not who) are to be scared, and (in the case of special deterrence) beaten, into submission? ${ }^{87}$

Positive general prevention did not threaten dogs with raised sticks, but instead addressed human beings capable of making choices, including the choice to follow or to break the law. It sought to deter no one, neither the person punished nor anyone else. It merely aimed to reinforce the "general legal consciousness" perhaps including, but certainly not limited to, the specific offender.

But positive general prevention was to be more than the kinder, gentler version of general deterrence, thus solving, or at least circumventing, the normative problems that had dogged general deterrence for centuries. It was to solve consequentialist theory's

also Paul Johann Anselm von Feuerbach, Lehrbuch des gemeinen in Deutschland gültigen peinlichen Rechts $§ 18$ (14th ed. Karl Joseph Anton Mittermaier ed. Giessen 1847) (reprint Scientia: Aalen 1973).

${ }^{86}$ Immanuel Kant, Metaphysics of Morals 472-73 (6:331-32) (Mary J. Gregor trans. \& ed. 1996)

${ }^{87}$ G.W.F. Hegel, Elements of the Philosophy of Right $\$ 99$ (Allen W. Wood ed. 1991). For a more detailed discussion of Hegels' theory of punishment, see Markus Dirk Dubber, Rediscovering Hegel's Theory of Crime and Punishment, 92 Michigan Law Review 1577 (1994).

${ }^{88}$ Claus Roxin, Strafrecht: Allgemeiner Teil 51 (3d ed. 1997). 
empirical problems as well. For not only special prevention, or rehabilitation, had run into empirical difficulties, captured dramatically in the "nothing works" slogan. General deterrence, too, had never quite managed to bolster its scientific claims with hard empirical evidence. There certainly was a strong common sense notion that punishment would have a deterrent effect, but not much else. But common sense hardly seemed enough for a theory of punishment whose central claim was that punishment without a point (or for its own sake) was patently illegitimate. Unlike retributivism, consequentialism was not to rest a state institution as intrusive and violent as punishment on some metaphysics of crime and punishment, or on some abstract principle of justice (such as the categorical imperative). Instead, what was needed was hard evidence of results. Without that evidence, consequentialism was no better than retributivism. To persist in punishing in the absence of evidence of punishment's beneficial effects would be barbaric indeed.

Deterrence theory's most embarrassing empirical problem is that the mere fact of crime appears to disprove it. After all, if the point of punishment is deterrence then it becomes difficult, at least after a while, to ignore the fact that crime persists, and even increases, despite continued punishment. Positive general prevention, however, is thought to blunt the force of this empirical objection, largely by virtue of its very positiveness, so to speak. Who knows, after all, what positive effects the threat and infliction of punishment might have on the lawabidingness of the lawabiding? The mere existence of considerable numbers of undeterrable offenders doesn't imply the absence of scores of people who never even consider a life of crime because they see their trust in the authority of law reaffirmed, all contrary appearances in the form of continued lawbreaking notwithstanding. Clearly, not everyone is committing crimes all the time. Why shouldn't that be the result of positive general prevention through punishment? ${ }^{89}$ Surely, punishment can claim to have made some contribution here.

This speculation, however, if it can be said to prove anything, proves not only the empirical soundness of positive general prevention, but of any method of preventive punishment, including through deterrence. And so one can find arguments that positive general prevention is attractive precisely because of the very absence of empirical evidence for its effectiveness - or more precisely, the impossibility of ever producing empirical evidence. For all intents and purposes, it is said, positive general prevention is empirically immune; it is "hardly falsifiable." 90

Nonfalsifiability might appear as an odd benefit of a punishment theory that is designed to combat the nonfalsifiability of retributivist metaphysics. In fact, at some point it becomes difficult to tell the difference between positive general prevention and retributivism. For many retributivists too were concerned with using punishment to manifest the authority of the state, or at least the force of criminal (or social, or moral, or legal) norms (see Binding above). Unlike most supporters of positive general prevention today, they did not claim that asserting the authority of law required any end beyond itself, but if achieving that end becomes so irrelevant as to not require verification (or even verifiability), then one might suspect that positive general prevention adds little to retributivism.

\footnotetext{
${ }^{89}$ Claus Roxin, Strafrecht: Allgemeiner Teil 51 (3d ed. 1997).

${ }^{90}$ Claus Roxin, Strafrecht: Allgemeiner Teil 51 (3d ed. 1997).
} 
The line between retributivism and consequentialism becomes particularly blurry in a recent, and quite influential, variety of positive general prevention. Echoing Hegel's theory of punishment as the negation of the negation (of crime), Günther Jakobs regards the function of criminal law as "contradicting the contradiction of norms defining the identity of society." "Punishment," in Jakobs's conception, "is not only a means for the maintenance of societal identity, but already is this maintenance itself." 91 As such, the efficacy of punishment is beyond empirical falsifiability; maintaining societal identity is what punishment means. ${ }^{92}$ That's not to say, of course, that retributivism, or any other theory of punishment that doesn't turn on empirical falsifiability, should for that reason be dismissed, only that nonfalsifiable varieties of positive general prevention cannot dismiss it for that reason.

The less emphasis is placed on the effects, the more weight is shifted onto the meaning of punishment. And the more positive general prevention insists that punishment is about meaning something, as opposed to accomplishing something (like prevention, say), the less it appears as a justification of punishment, as opposed to an analysis of it. At some point, positive general prevention becomes not a theory of punishment, but a function of punishment. Perhaps it is true that punishment "demonstrates to the community of law the inviolability of the legal order and thereby strengthens the population's loyalty to the law."93 But does this demonstration and strengthening justify punishment?

Here positive general prevention faces the same difficulties as the so-called expressive theory of punishment. The expressive theory of punishment, in fact, never claimed to justify punishment at all. The expression of the communal condemnation was not a purpose, or rationale, of punishment, but, as the title of the article popularizing it makes plain, a (not even the) "function of punishment." 94 As an expressive analysis of the function of punishment, positive general prevention fits into a long tradition of sociological accounts, reaching at least as far back as Durkheim, who regarded state punishment as a medium for the satisfaction of society's collective feelings of revenge and, for that reason, as playing a crucial role in the maintenance of communal identity in modern societies devoid of substantive commonalities. ${ }^{95}$

\section{Theories and Functions of Punishment}

Now, attempts to turn sociological accounts of the expressive function of punishment into a normative theory of punishment are nothing new, nor are they unique to German criminal legal science. In the early twentieth century the English idealist philosopher A.C. Ewing developed an account of state punishment as denunciation on behalf of the community. ${ }^{96}$ In Germany at around the same time, Heinrich Maier set out a theory of

\footnotetext{
${ }^{91}$ Günther Jakobs, Das Strafrecht zwischen Funktionalismus und “alteuropäischem” Prinzipiendenken, 107 ZStW 843, 844 (1995).

${ }^{92}$ Id. at 845.

${ }^{93}$ Claus Roxin, Strafrecht: Allgemeiner Teil 50 (3d ed. 1997) (quoting BVerfGE 45, 255 f.).

${ }^{94}$ Joel Feinberg, The Expressive Function of Punishment, in Doing and Deserving 95 (1970).

${ }^{95}$ Emile Durkheim, The Division of Labor in Society 73, 96 (George Simpson transl. 1933); see also The Power to Punish: Contemporary Penality and Social Analysis 44 (David Garland \& Peter Young, eds. 1983).

${ }^{96}$ A.C. Ewing, The Morality of Punishment 24 (1929).
} 
punishment as medium of the people's common consciousness (Volksbewußtsein), in earthly analogy to God's heavenly condemnation in the afterlife. ${ }^{97}$ More recently, Richard Burgh has argued that punishment compensates society by "emphatically expressing" its condemnation of criminal wrongdoing. ${ }^{98}$

The problem here is, once again, that these normative theories of punishment as expression are avowedly retributivist, with no interest whatever in the preventive consequence of punishment, other than as perhaps a salutary side effect to a practice that must be justified on retributive, or compensatory, grounds. Independent of the merits of a retributive justification of punishment, positive general prevention can ill afford being collapsed into retributivism as it derives much of its appeal precisely from its steadfast opposition to the retributivist claim that punishment is simply quia peccatum est. ${ }^{99}$

Then there is the related observation that an expressive theory of punishment, even if it could justify something, might justify expression, not punishment. If expressing condemnation is what punishment is about, why would we not replace punishment with condemnation rituals, including the public reading of the offense of conviction and the pronouncement of various levels of condemnation, ranging from the slight to the severe and the stern? Moreover it would seem that we would be obliged to do away with punishment altogether, given that surely the pain of the condemned is considerably less than the pain of the punished. A consequentialist balancing of costs and benefits, or pains and pleasures, under the principle of parsimony would seem to require nothing less. $^{100}$ In that case, the expressive theory of punishment would have justified not punishment, but its abolition.

In fact the expressive theory of punishment recently has been invoked in support of calls for an alternative, if not to punishment in general, then to imprisonment in particular. ${ }^{101}$ Under this view, the community should express its condemnation directly through shaming, rather than indirectly through more familiar modern punishments, most importantly imprisonment, which do a poor of job of expressing public condemnation precisely because their infliction has been removed from public view. While imprisonment might indirectly express condemnation to the prison inmate, public shaming would not only send a clearer message to the shamed but would also send a message to the law-abiding community, which otherwise would be shut out from whatever expressive punishing might occur behind prison walls. Shaming is the alternative sanction of choice, because only it - unlike other alternative (meaning noncarceral) sanctions such as fines, probation, or community service - "unambiguously express[es] condemnation." 102

\footnotetext{
${ }^{97}$ Heinrich Maier, Psychologie des emotionalen Denkens 692 (Tübingen 1908) (quoted in Ernst Beling, Die Vergeltungsidee und ihre Bedeutung für das Strafrecht 28 n.1 (Leipzig 1908)).

${ }^{98}$ Richard Burgh, Guilt, Punishment and Desert, in Responsibility, Character, and the Emotions (Ferdinand Schoeman, ed. 1987), at 330.

${ }_{99}$ Then again, perhaps the Germans are simply protesting too much. Perhaps, despite all their antiretributive bluster, they are all retributivists at heart. George Fletcher, for one, suspects they are but "[retributive] sheep in [consequentialist] wolves' clothing." George P. Fletcher, Utilitarismus und Prinzipiendenken im Strafrecht, 101 ZStW 803, 814 (1989).

${ }^{100}$ On the principle of parsimony, see Jeremy Bentham, ch. 14, § 13 (1823) (reprint Hafner: New York 1948).

${ }^{101}$ See, e.g., Dan M. Kahan, What Do Alternative Sanctions Mean?, 63 U. Chi. L. Rev. 591 (1996).

${ }^{102}$ Id. at 592.
} 
Note that these "alternative sanctions" are very much in keeping with the spirit of positive general prevention. Their primary audience is general, rather than specific: they focus not on shaming's effect on the offender - without excluding her from the audience, however - but on the community, which reassures itself that its norms remain strong, even and especially in the face of their violation by the proper objects of punitive shame.

Shaming also is positive because it prevents crime by capitalizing on the "'moralizing' or 'moral educative' effect of punishment," ${ }^{103}$ rather than relying on mere threats of pain.

Whether shaming also is preventive is a more difficult question. While proponents of shaming sanctions invoke their presumed preventive effect in support, their argument rests not on prevention, but on expression, not on effect, but on meaning. Shaming is an appropriate sanction because it properly expresses communal condemnation, not because it promises lower crime rates.

But, as we've seen, much of the literature of positive general prevention doesn't seem particularly concerned with prevention either. In some of its variants, at least, positive general prevention makes it clear that the function of punishment is not prevention, but maintaining communal identity.

Presumably, German proponents of positive general prevention nonetheless would recoil in horror at the suggestion that shaming sanctions be reintroduced into the punitive arsenal of modern criminal law. After all, the primary sanction in German criminal law is not imprisonment, but the fine, so that calls for shaming as an alternative to imprisonment are inapposite. Still, the difference between positive general prevention and expressive shaming is not conceptual, but merely conventional. If it turns out that the proponents of expressive shaming are correct and that shaming expresses condemnation, and reaffirm communal identity, as well as, if not better than, the paradigmatic sanction (imprisonment in the United States, fines in Germany), then positive general preventionists cannot reject expressive shaming out of hand. German communal norms may be different from American ones on this point, but it's only this presumed empirical difference that would militate against the introduction of shaming penalties on positive general preventive grounds in Germany.

The problem with positive general prevention as an expressive theory of punishment thus is not only that it cannot justify punishment as a mode of expression. Perhaps as important, it can justify any mode of expression that happens to - or in the absence of empirical falsifiability is said to - signify communal solidarity under common norms through communal condemnation.

Still, the motives behind the project of constructing a theory of positive general prevention are laudable. The theory of positive general prevention represents an effort to construct a comprehensive theory of punishment that addresses the tensions between consequentialism and retributivism without ignoring them, to extract the attractive features of both approaches and weld them together into a new, better, whole. Its ambition is to move beyond the mere compilation of inconsistent theories of punishment, on one hand, and the dogged insistence of one theory's superiority, on the other. As such, the theory of positive general prevention illustrates the scientific spirit motivating the project of German criminal law as a whole. As a matter of science, the problem of punishment must be solved, and a theory of punishment must be discovered. Under this

${ }^{103}$ Id. at 603. 
view, the recourse to pragmatism is simply unacceptable, especially in a matter as foundational as the theory of punishment. By contrast, an Anglo-American judge experiencing the opposing pull of consequentialist and retributive theories of punishment may well be content "to equivocate, oscillating between these poles, tempering justice with mercy, just deserts with utility calculations, in varying pragmatic ways." 104

\section{Rechtsgut: The Theory of Criminalization}

Another issue that has long befuddled Anglo-American criminal law is the significance, and meaning, of harm. ${ }^{105}$ Relatedly, the precise function of criminal law has proved remarkably difficult to define. According to a widely shared assumption criminal law is thought to be about the prevention of harm; but if that is so, the question remains what, exactly, counts - or should count - as criminal harm.

At this point, the Anglo-American criminal lawyer may well invoke the authority of John Stuart Mill and his celebrated "harm principle," according to which the state can only use its coercive might to prevent one person from harming another, but not from harming himself, nor from doing, or thinking, anything that doesn't amount to harming another, no matter how despicable the action or thought might be. ${ }^{106}$

But why should that be? Why, we might ask ourselves, should law in general, and criminal law in particular, concern itself with "harms," and with nothing else? What is it about "harm" - as opposed to, say, "offense" or "risk" or "inconvenience" - that legitimizes state action? One might tell a utilitarian story about pleasure and pain, with harm being the infliction of pain, but that too begs the question, as clearly not any type of pain, no matter what quality (psychological vs. physical) or quantity (slight vs. serious) triggers the state's right to invoke the criminal law. Presumably a story about the point of criminal law, and about the nature of criminal harm, would have something to say about "crime" and about "law." Otherwise we might learn much about morality or ethics or state action or the varieties of human suffering, but very little about criminal law in particular.

Perhaps, instead of turning to Mill, the Anglo-American criminal lawyer might wish to consult German criminal law; for German law offers - or at least appears to offer - an account of the nature of criminal harm and the point of criminal law: the theory of Rechtsgut. ${ }^{107}$

Rechtsgut, or legal good, is one of the foundational concepts underpinning the system of German criminal law. It is so basic and essential a concept that German criminal

\footnotetext{
${ }^{104}$ United States v. Blarek, 7 F. Supp. 2d 192 (E.D.N.Y. 1998) (Weinstein, J.).

${ }^{105}$ See, e.g., Stephen Schulhofer, Harm and Punishment, 122 Univ. of Penn. Law Review 1497 (1974).

106 John Stuart Mill, On Liberty 10-11 (Norton Critical Edition, 1975); see, e.g., Claire Finkelstein, Positivism and the Notion of an Offense, 88 Calif. L. Rev. 335 (2000); Joel Feinberg, The Moral Limits of the Criminal Law (1988).

${ }^{107}$ See, e.g., Andrew von Hirsch, Der Rechtsgutsbegriff und das "Harm Principle," 149 Goltdammer's Archiv für Strafrecht 2 (2002); see also Antony Duff, Theories of Criminal Law, in The Stanford Encyclopedia of Philosophy (Winter 2002 Edition), Edward N. Zalta (ed.), http://plato.stanford.edu/archives/win2002/entries/criminal-law/ (defining Rechtsgut as "a good which the law properly recognises as being necessary for social peace or for individual well-being, and as therefore meriting legal protection"). For a very interesting exploration of the concept of Rechtsgut from a comparative perspective, see now Die Rechtsgutstheorie: Legitimationsbasis des Strafrechts oder dogmatisches Glasperlenspiel (Roland Hefendehl et al. eds. 2003).
} 
lawyers find it difficult to imagine a system of criminal law without it. The concept of legal good serves several crucial functions, at various levels of generality within the German criminal law system. Most fundamentally, the concept of legal good defines the very scope of criminal law. By common consensus, the function of criminal law is the "protection of legal goods," and nothing else. ${ }^{108}$ Anything that does not qualify as a legal good falls outside the scope of criminal law, and may not be criminalized. A criminal statute, in other words, that does not even seek to protect a legal good is prima facie illegitimate. This principle has been used to decriminalize various morals offenses, such as homosexual sex and the distribution of pornography. ${ }^{109}$

To perform this basic critical function, the concept of legal good must be defined with reasonable clarity and it must be given normative bite. There is much less of a consensus in the German literature on these two points, however, than there is on the general commitment to the concept of Rechtsgut in the abstract.

\section{A. Positivism and Normativism}

To appreciate the scope of the concept of Rechtsgut in the literature, as well as the variety of its manifestations, let's consider the treatment of the topic in two leading, and fairly representative, treatises. Hans-Heinrich Jescheck and Thomas Weigend, in their popular Textbook of Criminal Law: General Part, declare categorically that "[c]riminal law has the objective of protecting legal goods," 110 and then go on to explain that legal goods, or "life goods " (Lebensgüter), come in two varieties. Among "elementary life goods" that "are indispensable for the coexistence of humans in the community (Gemeinschaft) and therefore must be protected by the coercive power of the state through public punishment" one finds,

for example, human life, bodily integrity, personal freedom of action and movement, property, wealth, traffic safety, the incorruptibility of public officials, the constitutional order, the public peace, the external security of the state, the impunity of foreign state organs and indicia, the security of national, ethnic or cultural minorities against extermination or undignified treatment, international peace. ${ }^{111}$

Besides these elementary goods there are also those that "consist exclusively of deeply rooted ethical convictions of society (Gesellschaft) such as the protection good of the criminal prohibition of cruelty against animals,"112 which "become legal goods through their adoption into the legal order."

\footnotetext{
${ }^{108}$ See, e.g., Armin Kaufmann, Die Aufgabe des Strafrechts 5 (1983) ("no one in criminal legal science seriously doubts that the protection of legal goods is the objective of criminal law"); Diethelm Kienapfel, Strafrecht: Allgemeiner Teil 39 (4th ed. 1984) ("despite some criticism" legal good remains "one of the immovable cornerstones of criminal law doctrine, today more than ever").

${ }^{109}$ Claus Roxin, Strafrecht: Allgemeiner Teil I, at 11-12 (3d ed. 1997); Hans-Heinrich Jescheck \& Thomas Weigend, Lehrbuch des Strafrechts: Allgemeiner Teil 104-05 (5th ed. 1996).

${ }^{110}$ Hans-Heinrich Jescheck \& Thomas Weigend, Lehrbuch des Strafrechts: Allgemeiner Teil 6 (5th ed. 1996) (emphasis in original).

${ }^{111}$ Hans-Heinrich Jescheck \& Thomas Weigend, Lehrbuch des Strafrechts: Allgemeiner Teil 7 (5th ed. 1996).

${ }^{112}$ Id.
} 
By contrast, Claus Roxin, in his influential Criminal Law: General Part, doesn't assemble a list of legal goods, not even an exemplary one. In passing, however, he does mention a number of things that have been considered legal goods at some point in time, including, in order of appearance in the text,

\begin{abstract}
life, bodily integrity, honor, the administration of law, ethical order, sexual autonomy, property, the state, the currency, dominant moral opinions, heterosexual structure of sexual relations, undisturbed operation of administration, purity of German blood, public peace, traffic congestion, the life and well-being of animals, the environment, morality, "purity of soil, air, water, etc.," the variety of species in flora and fauna, maintenance of intact nature, the people's health, life contexts as such, purity of the system of proof. ${ }^{113}$
\end{abstract}

Also unlike Jescheck-Weigend, Roxin hazards a definition of Rechtsgut:

Legal goods are conditions or chosen ends, which are useful either to the individual and his free development within the context of an overall social system based on this objective, or to the functioning of this system itself. ${ }^{114}$

Roxin's definitional venture is motivated by an attempt to put some teeth into the concept of legal good. While Jescheck-Weigend appear content to follow up their declaration that criminal law protects legal goods with a list of legal goods the criminal law in fact does protect, Roxin strives to give the concept of legal good normative bite. The concept of legal good by itself is supposed to tell the legislature "what it may punish and what it shall leave without punishment." 115

The tension between positivism (here represented by Jescheck-Weigend) and normativism (Roxin) is inherent in the concept of legal good itself. On the face of it, the concept appears to be in conflict with itself, for it conjoins two very different concepts: Recht and Gut. The translation of Gut, as "good," is fairly straightforward. What is not so clear is what sort of "good" one has in mind here. While the term is familiar enough, it's familiar from moral, or perhaps political, philosophy, but not from legal theory, never mind from blackletter law. What's more, those disciplines that do concern themselves with the concept of "good" (or "goods") have had considerable difficulty defining it. Even if moral theory had produced a neat and widely shared notion of good, it's not immediately obvious why that notion should have any application to the field of law, particularly since German criminal law since P.J.A. Feuerbach (or Kant, whoever came first) has maintained a strict distinction between morality and legality, and criminal law especially. ${ }^{116}$

\footnotetext{
${ }^{113}$ Id. at $12-23$.

${ }^{114}$ Id. at 15.

${ }^{115} \mathrm{Id}$. at 11.
}

116 Paul Johann Anselm von Feuerbach, Kritik des natürlichen Rechts also Propädeutik zu einer Wissenschaft des natürlichen Rechts (1796); Immanuel Kant, Metaphysics of Morals (1797). On the relationship between Feuerbach's and Kant's views on this issue, see Joachim Bohnert, Paul Johann Anselm Feuerbach und der Bestimmtheitsgrundsatz im Strafrecht 24-26 (1982); Oskar Döring, Feuerbachs Straftheorie und ihr Verhältnis zur Kantischen Philosophie, 3 Kantstudien Ergänzungshefte 23-26 (1907); Richard Hartmann, P.J.A. Feuerbachs politische und strafrechtliche Grundanschauungen 16 (1961); Wolfgang Naucke, Wolfgang. Kant und die psychologische Zwangstheorie Feuerbachs 44-50 (1962); on the question of firstness in particular, see Döring, supra, at 40; Hartmann, supra, at 10 \& n. 23. While Kant characterized the criminal law as a formulation of the categorical imperative and viewed the formation of 
But it is the other of the concepts welded together in the word "Rechtsgut" that presents the real difficulty. Recht is well-known for its ambiguity. ${ }^{117}$ With no equivalent in the English language it straddles the distinctions between justice and law, rightness and legality, natural and positive law, and even rights and right. ${ }^{118}$ This inherent ambiguity means, for one, that the question about the relevance of an apparently moral concept like "good" to a system of law cannot simply be answered - as it sometimes is - by pointing out that we are, after all, talking about a legal good, rather than a moral one. The mere invocation of the label "Rechtsgut" - with an appropriate emphasis on the first syllable cannot stem any unwanted incursion of moral notions into law in general, and criminal law in particular.

\section{B. From Feuerbach to Birnbaum}

The impression of a concept at odds with itself is only strengthened when one considers the origins and subsequent development of Rechtsgut. In a very real sense, the tension between a positivist and a normative approach to the concept of legal good is as old as the concept itself. According to the standard account, the concept of legal good was discovered by an otherwise rather undistinguished criminal law scholar by the name of Birnbaum, who first reported his discovery in an often cited article published in $1834 .^{119}$ In that article, Birnbaum attacked Feuerbach's view of crime as a violation of "subjective right." According to Feuerbach, in committing a crime the offender didn't just violate "the law," or "a statute," but the rights of her individual victim. Birnbaum pointed out that this view of crime was much too narrow, as it couldn't account for a great many criminal statutes which did not concern themselves with violations of individual rights at all, and yet were not considered to be any less criminal as a result.

Feuerbach's cramped view of crime might work for traditional crimes like murder and theft, but it didn't have room for such familiar crimes as "unethical and irreligious acts." 120 Birnbaum had a point. In fact, Feuerbach himself had never denied that crimes against morality and religion were crimes, even though everyone agreed they didn't violate anyone's individual rights and therefore didn't fit Feuerbach's definition of crimes as violations of individual rights. Instead he had, with some embarrassment,

the state as a moral duty, Feuerbach restricted the role of morality in the justification of punishment to the moral notion of freedom underlying the decision of persons in the state of nature to form a state. Bohnert, supra, at 24-26; Döring, supra, at 23-26; Hartmann, supra, at 16; Naucke, supra, at 44-50. According to Feuerbach, persons endowed with moral freedom decide to restrict their freedom by creating a higher authority for the purpose of protecting this more limited form of freedom, i.e., legal freedom. Naucke, supra, at 44-50. As the protector of the legal freedom of its citizens, the state may-indeed must-do anything in its power to prevent attacks on this freedom. Naucke, supra, at 50.

${ }^{117}$ See, e.g., George P. Fletcher, The Right and the Reasonable, 98 Harv. L. Rev. 949 (1985).

118 The Recht in Birnbaum's Rechtsgut is not the Recht that is violated in Feuerbach's view of crime. The former is "the law," the latter "right," as in individual rights. To confuse things further, among Birnbaum's legal goods_-goods protected by the law_-are individual rights. An individual right protected by the law, then, would become a Rechtsrecht.

119 Johann Michael Franz Birnbaum, Ueber das Erforderniß einer Rechtsverletzung zum Begriffe des Verbrechens, 15 Archiv des Criminalrechts (Neue Folge) 149 (1834).

${ }^{120}$ Id. at 178 . 
simply categorized them as "crimes in the broad sense" and labelled them "police offenses." 121

Birnbaum clearly did a much better job capturing the nature of crime as a matter of positive law. Instead of a violation of individual rights (Rechte), a crime was now to be regarded as a violation of or a threat to goods (Güter) protected by the state. ${ }^{122}$ But whatever Birnbaum's definition of crime gained in accuracy, it lost in critical purchase.

Eventually the notion of legal good, rather than limiting the power of the state to criminalize, turned into a convenient trope for its expansion. By the late nineteenth century, when Birnbaum's discovery of the legal good was rediscovered by the committed positivist architects of the new national German criminal law, Karl Binding chief among them, the point of the legal good was to justify the expansion of criminal law beyond the protection of individual rights to the protection of communal goods, societal interests, and eventually the state itself. ${ }^{123}$ Legal goods became "interests of the law," transforming law from a means to an end in itself. ${ }^{124}$ If crime was thought to violate any right, it was not the rights of individuals but the state's right to obedience. ${ }^{125}$

Accordingly, Binding defined legal good as "anything that the legislature considers valuable and the undisturbed retention of which it therefore must ensure through norms." "126 In Binding's influential norm theory of criminal law, legal goods (e.g., life) were protected by norms (e.g., do not kill) that the legislature, in its discretion, translated into legal prescriptions and prohibitions, including, but not limited to, criminal statutes (e.g., whoever causes the death of another person is guilty of murder and punishable by death).

At the same time as the move from the protection of individual rights to that of legal goods broadened the scope of criminal law, the move from violations to threats widened its grasp. Where criminal law was once - at least in theory, however awkwardly limited to the punishment of violations of individual rights, it now reached the prevention of threats to any good, individual or not, which the state declared worthy of its penal protection.

Since Binding's rediscovery of Birnbaum, the basic framework of the occasionally heated debate about the definition and the function of the concept of legal good have remained fairly constant. Contributors to the debate took their place along the spectrum marked by Feuerbach's notion of crime as a violation of individual right and Binding's as a threat to state interests. Even Nazi criminal law, after some initial attempts to discard the notion of legal good altogether as an outdated liberal constraint upon state power, was content to develop new legal goods worthy of penal protection, rather than doing away

${ }^{121}$ P.J.A. Feuerbach, Lehrbuch des gemeinen in Deutschland geltenden peinlichen Rechts $\S 27$ (1st ed. 1801).

${ }^{122}$ Johann Michael Franz Birnbaum, Ueber das Erforderniß einer Rechtsverletzung zum Begriffe des Verbrechens, 15 Archiv des Criminalrechts (Neue Folge) 149, 179 (1834) ("any violation of or threat to a good that is to be guaranteed by the state equally to everyone and that is attributable to the human will").

${ }_{123}$ See generally Peter Sina, Die Dogmengeschichte des strafrechtlichen Begriffs "Rechtsgut" 39-69 (Basel: Helbing \& Lichtenhahn 1962).

${ }^{124}$ See Karl Binding, Die Normen und ihre Übertretung, vol. 1, at 189 (1st ed. Leipzig 1872) ("the condition caused by the prohibited conduct violates the interests of the law").

${ }^{125}$ Karl Binding, Die Normen und ihre Übertretung, vol. 1, at 299, 308 n.1, 369 (1st ed. Leipzig 1872).

${ }^{126}$ Karl Binding, Handbuch des Strafrechts, vol. 1, at 169 (Leipzig 1885). 
with the concept altogether (e.g., "race and the substance of the people," "Germanness"). ${ }^{127}$

\section{Constitutional Foundations?}

Today the formal-positivist and the material-normative approach to the concept of legal good are represented by Jescheck-Weigend and Roxin, respectively, and among many others. What's "new" about Roxin is the attempt to derive the content of legal good not from some more or less explicit notion of "law" or "good," but from constitutional principles, for only they limit legislative discretion in a modern democratic state: "A concept of legal good that constrains penal policy . . . can only derive from those objectives of our law state (Rechtsstaat) grounded in the freedom of the individual which are articulated in the Basic Law," ${ }^{128}$ i.e., the German constitution. Just what these constitutional principles are, however, Roxin does not say. From the quoted declaration, he proceeds immediately to the above-quoted definition of legal goods as "conditions or chosen ends, which are useful either to the individual and his free development within the context of an overall social system based on this objective, or to the functioning of this system itself." 129

Roxin's failure to derive his definition of legal good from the constitution is of course problematic, given that he simultaneously asserts that any such definition must be constitutionally derived. Upon closer inspection one begins to suspect that the definition derives not from its source, constitutional or not, but from its effect. So Roxin explains that the inclusion of "chosen ends," in addition to preexisting "conditions" (presumably including individual rights), was meant to "express" a prior, unexplored, judgment that his view of legal good does not exclude by definition any crimes that Anglo-American lawyers might call mala prohibita, and that he calls "duties to obey norms generated by law itself.,"130 In other words, he insists on critical bite, but not on too much.

It is no surprise, therefore, that Roxin spends considerably more time illustrating various applications of his definition than he does justifying it. The definition is correct, the implication appears to be, because it leads to correct results, legitimizing just the right sorts of crimes, while delegitimizing only those that are beyond the pale of the state's penal power. In fact, Roxin identifies not a single case of a German criminal statute that is illegitimate because it does not protect a legal good.

The statutes, and policies, that fail Roxin's legal good test are either fanciful or obsolete. "Arbitrary threats of punishment" are illegitimate because they do not protect legal goods. No one may be forced, by fear of punishment, to pay homage to some "symbol" or other, for this "serves neither the freedom of the individual in a state committed to freedom nor the ability of a social system based on such principles to function." ${ }^{131}$ The purity of German blood likewise doesn't count as a legal good because

\footnotetext{
127 Peter Sina, Die Dogmengeschichte des strafrechtlichen Begriffs "Rechtsgut" 74 (Basel: Helbing \& Lichtenhahn 1962) ("Rasse und Volkstum"; "Deutschheit").

${ }^{128}$ Claus Roxin, Strafrecht: Allgemeiner Teil I, at 15 (3d ed. 1997).

${ }^{129}$ For critical analysis of attempts to ground legal goods in constitutional principles, see generally Ivo Appel, Verfassung und Strafe: Zu den verfassungsrechtlichen Grenzen staatlichen Strafen 372-79 (1998).

${ }_{130}$ Claus Roxin, Strafrecht: Allgemeiner Teil I, at 15 (3d ed. 1997).

${ }^{131}$ Claus Roxin, Strafrecht: Allgemeiner Teil I, at 15 (3d ed. 1997).
} 
"protecting ideological objectives through penal norms is prohibited."132 Criminalizing homosexual sex too is improper. Morally offensive behavior, Roxin points out, doesn't violate legal goods because it doesn't interfere with "the social system's ability to function." "133 In fact, it's the criminalization of morally offensive behavior, rather than the behavior itself, which causes such interference "because it creates unnecessary societal conflict by stigmatizing socially integrated humans."134

All existing criminal statutes pass the test, even if not always with flying colors. So Roxin struggles to justify the continued punishability of assisted suicide, which arguably interferes with no legal good, on the ground that it's difficult to prove the decedent's "autonomous decision" to end her life and that, at any rate, "the norm of protection of life demands the tabooization of others' life."135 Drug criminal law is legitimate - despite strong criticism that it protects no legal good, individual or communal ${ }^{136}$ - because it abates the dangers of drugs "for consumers incapable of responsibility"; the crime of abortion protects the fetus" "emerging life," which is a legal good because the German Constitutional Court has held that it is constitutionally protected; cruelty to animals is properly criminalized not because it offends deeply held and widely shared moral convictions (which do not qualify as legal goods in Roxin's definition), but because "it is to be assumed that the legislature, in a kind of solidarity among creatures, also regards the higher animals as fellow creatures, or 'foreign brothers,' and protects them as such;" and environmental crimes too pass muster because "the variety of the species in flora and fauna and the preservation of intact nature belong to a life with human dignity." Not even "symbolic legislation," including obviously ineffective policies designed merely to placate voters or to signal the legislature's commitment to certain values, fails the legal good test, at least not without "a comprehensive study from the perspective of criminal and constitutional law," which, however, is yet to be undertaken. ${ }^{137}$

Considering the toothlessness of Roxin's normative theory of legal good, its bark turns out to be worse than its bite. In fact, one might even wonder just what critical point the concept of legal good retains, when all is said and done. ${ }^{138}$ Even Roxin himself acknowledges that, by his own account, it's not clear just what the notion of legal good adds to constitutional constraints upon criminal lawmaking. (He concludes that the

132 Claus Roxin, Strafrecht: Allgemeiner Teil I, at 15 (3d ed. 1997).

133 It presumably goes without saying that consensual, but immoral, behavior does not interfere with "conditions or chosen ends, which are useful either to the individual and his free development within the context of an overall social system based on this objective," the first prong of Roxin's definition of legal good.

134 Claus Roxin, Strafrecht: Allgemeiner Teil I, at 16 (3d ed. 1997). We may infer, therefore, that criminalizing immoral acts would not be merely illegitimate, but would itself be criminalizable as a violation of a legal good.

${ }^{135}$ Claus Roxin, Strafrecht: Allgemeiner Teil I, at 18 (3d ed. 1997).

136 Cornelius Nestler, Betäubungsmittelstrafrecht, Grundlagen und Kritik, in Arthur Kreuzer, Handbuch des Betäubungsmittelstrafrechts (1997) ("Volksgesundheit").

${ }^{137}$ Claus Roxin, Strafrecht: Allgemeiner Teil I, at 18-19 (3d ed. 1997).

${ }^{138}$ Note also that, even among proponents of a normative definition of legal good, it often remains unclear what is supposed to happen if a criminal statute runs afoul of the requirement that it protect a legal good, however defined. Is it invalid, or unconstitutional, or is the critical function of the concept limited to policy pointers that the legislature is free to ignore? See Ivo Appel, Verfassung und Strafe: $\mathrm{Zu}$ den verfassungsrechtlichen Grenzen staatlichen Strafen 351-55 (1998). 
concept can still serve to "bundle" the various constitutional limitations. ${ }^{139}$ ) After all, the definition of legal good is supposed to be derived exclusively from constitutional principles, as it must be as no other constraints upon the legislature are said to be permissible. ${ }^{140}$

\section{Internal Constraints}

At this point, it's worth noting that even a merely - and explicitly - positivist notion of legal good, such as the one favored by Jescheck-Weigend, is not without critical potential, though from within an existing system of criminal law, rather than from without. Even if the ends of criminal law are beyond reproach, the means need not be. In German criminal law, a criminal statute that sets out to protect a legal good - however defined - and therefore has the proper end, may nonetheless be open to criticism if it is insufficiently connected to that good, and thus constitutes an improper means. This means-ends test has been used to criticize so-called "abstract dangerousness offenses," which criminalize conduct that in the abstract poses a threat to some legal good, without any need to prove that the specific conduct posed such a threat in fact. ${ }^{141}$ The classic example here is driving while intoxicated. ${ }^{142}$

Recall that Birnbaum expanded the scope of criminal law not only in breadth, but also in depth, by recognizing the punishability of mere threats to legal goods, as opposed to actual violations. Modern German criminal law, and in fact modern criminal law in general, has been much concerned with reaching, and neutralizing, ever more remote, and ever more abstract, threats to legal goods. ${ }^{143}$ German criminal law distinguishes between concrete and abstract dangerousness offenses. In the former case, the definition of the offense includes actual endangerment, as in the offense of "endangering rail, ship, and air traffic" which criminalizes "endanger[ing] another's life, limb, or property of significant value" 144 in certain circumstances. Abstract endangerment offenses, by contrast, do not include actual endangerment in their definition. They instead cover conduct that "typically creates a concrete danger," 145 whether or not that danger was in fact created by the particular conduct in question. Examples include slander, which requires only an act

\footnotetext{
${ }^{139}$ Claus Roxin, Strafrecht: Allgemeiner Teil I, at 16 (3d ed. 1997).

${ }^{140}$ Note, however, that this requirement of constitutional origin does not apply to other limitations on the legislature's power to make criminal law. Roxin, for one, does not lay similar stress on the constitutional foundation of the principles of the general part, as opposed to the concept of legal good, which constrains the scope of the special part. While constitutional status may well be claimed for something as central as the guilt principle (Schuldprinzip), there is no doubt that the principle's authority does not derive from that status. See, e.g., Claus Roxin, Strafrecht: Allgemeiner Teil I, at 746-47 (3d ed. 1997).

${ }^{141}$ See, e.g., Claus Roxin, Strafrecht: Allgemeiner Teil I, at 19-21 (3d ed. 1997) (discussing literature).

${ }^{142}$ Roxin sees no problem with this offense, however, because it clearly defines the proscribed conduct and bears a manifest relationship to legal goods (life, limb, property). Claus Roxin, Strafrecht: Allgemeiner Teil I, at 20 (3d ed. 1997) (discussing literature).

${ }^{143}$ On this phenomenon in American criminal law, see Markus Dirk Dubber, Policing Possession: The War on Crime and the End of American Criminal Law, 91 Journal of Criminal Law \& Criminology 829 (2002).

${ }^{144} \mathrm{StGB} \& 315 \mathrm{a}$.

${ }^{145}$ Hans-Heinrich Jescheck \& Thomas Weigend, Lehrbuch des Strafrechts: Allgemeiner Teil 264 (5th ed. 1996).
} 
"capable of" stigmatizing another ${ }^{146}$ and drunk driving, which requires no showing that the drunk driver posed a threat to anyone or anything. ${ }^{147}$

Finally, a criminal statute that does set out to protect a legal good still may be illegitimate if it is not necessary to achieve its end. The criminal law, in other words, is said to be the state's ultima ratio in its effort to protect legal goods; it must employ less intrusive, civil, means if they can provide sufficient protection for the legal good in question. The status, and origin, of this so-called subsidiarity principle of German criminal law is not entirely clear. Roxin claims, once again, that the ultima ratio principle derives from the constitution, in this case the principle of proportionality which, he continues, "can be deduced from the constitutional principle of the rule of law: Since criminal law enables the harshest of all state interferences with the liberty of the citizen, it may only be applied if milder means do not promise sufficient success."148 Later on, however, Roxin acknowledges that the legislature enjoys wide discretion in choosing among available means, criminal and noncriminal, concluding somewhat anticlimactically "the subsidiarity principle is more of a guideline for penal policymaking than a compelling requirement." 149

\section{E. Doctrinal Significance}

Apart from its various critical functions, external or internal, toothful or not, the notion of legal good performs several more mundane, doctrinal, tasks. The justification of necessity, for instance, requires a balancing of the affected legal goods (the protection of one legal good making the violation of the other necessary). ${ }^{150}$ The American Model Penal Code captures very much the same idea when it allows for a justification of "choice of evils" in the case of "[c]onduct which the actor believes to be necessary to avoid a harm or evil to himself or to another is justifiable, provided that . . . the harm or evil sought to be avoided by such conduct is greater than that sought to be prevented by the law defining the offense charged.",151

The balancing act required takes into account both the relative significance of the legal good, and the degree of its interference. So "personality values" (Persönlichkeitswerte) - like "human freedom" - rank higher than "thing goods" (Sachgüter) - like "property" - and "life and limb" trump not only other "personality values" but also "supraindividual legal goods."152 Yet trivial interferences with "personality values" may be justified for the sake of preventing serious interferences with "thing goods," such as a minor assault necessary to avert a major fire. ${ }^{153}$ The origin, as well as the precise order, of the ranking remains, once more, somewhat doubtful. As

\footnotetext{
${ }^{146}$ StGB $\S 186$.

147 StGB $§ 316$.

${ }^{148}$ Claus Roxin, Strafrecht: Allgemeiner Teil I, at 26-27 (3d ed. 1997).

${ }^{149}$ Claus Roxin, Strafrecht: Allgemeiner Teil I, at 27 (3d ed. 1997).

${ }^{150}$ Claus Roxin, Strafrecht: Allgemeiner Teil I, at 621 (3d ed. 1997).

151 § 3.02; Markus D. Dubber, Model Penal Code 194-201 (2002).

152 Claus Roxin, Strafrecht: Allgemeiner Teil I, at 621, 622 (3d ed. 1997).

${ }^{153}$ Claus Roxin, Strafrecht: Allgemeiner Teil I, at 621 (3d ed. 1997).
} 
might be suspected, the ranking of legal goods on occasion is said to derive from constitutional principles. ${ }^{154}$

Certain de minimis conduct that fits the definition of an offense is nonetheless declared noncriminal (or not "subsumed" under the offense definition) because it does not "really" violate the legal good protected by the statute in question. So tipping the mailman is not bribery, playing penny poker not gambling, and calling your brother a bad name not a criminal insult. ${ }^{155}$ The Model Penal Code likewise provides for judicial dismissal of a prosecution for prima facie criminal conduct that "did not actually cause or threaten the harm or evil sought to be prevented by the law defining the offense or did so only to an extent too trivial to warrant the condemnation of conviction."156

German criminal law also distinguishes between different types of legal good that a criminal statute might protect, individual legal goods, such as life and liberty, and communal ones, such as peace and security. And it may make a doctrinal difference which type of legal good is implicated. For instance, self-defense isn't available against attacks on communal - as opposed to individual - goods. "Otherwise every citizen could set himself as auxiliary policeman and annul the state's monopoly on violence."157 That's not to say, however, that no justification would be available, just that the justification of self-defense would not. A citizen who wishes to defend communal goods against attack instead would have to rely on the justification of necessity. ${ }^{158}$

Consent too is available as a justification only in cases involving an offense protecting an individual legal good. ${ }^{159}$ Here the reason is that the individual cannot be justified in waiving the criminal law's protection of a communal legal good, i.e., of an interest that is not merely his own and therefore not his to give away. ${ }^{160}$

Though of no immediate doctrinal significance, the role of the concept of legal good as a method of categorization also deserves mention. The special part of the German criminal code is divided up into sections which contain offense definitions designed to protect a common legal good or set of legal goods, including "crimes against peace" and "crimes endangering the democratic rule of law" (sec. 1), "crimes against sexual autonomy" (sec. 13), "crimes against personal freedom" (sec. 18), and "crimes against

${ }^{154}$ Ivo Appel, Verfassung und Strafe: Zu den verfassungsrechtlichen Grenzen staatlichen Strafen $372-79$ (1998) (focusing on the alleged constitutional foundation of the distinction between higher legal goods worthy of penal protection and lesser ones).

${ }^{155}$ Claus Roxin, Strafrecht: Allgemeiner Teil I, at 243 (3d ed. 1997).

156 § 2.12; Markus D. Dubber, Model Penal Code 180-82 (2002).

${ }^{157}$ Claus Roxin, Strafrecht: Allgemeiner Teil I, at 550 (3d ed. 1997).

${ }^{158}$ Claus Roxin, Strafrecht: Allgemeiner Teil I, at 613 (3d ed. 1997) (necessity).

159 This is true regardless of whether consent is addressed at the first level of analysis_-dealing with the question of whether an offense was committed - or at the second-dealing with the question of whether the offense can be justified. See Claus Roxin, Strafrecht: Allgemeiner Teil I, at 462-65 (3d ed. 1997) (offense); Hans-Heinrich Jescheck \& Thomas Weigend, Lehrbuch des Strafrechts: Allgemeiner Teil 375-76 (5th ed. 1996) (justification); see generally Theodor Lenckner, in Schönke-Schörder, Strafgesetzbuch: Kommentar 486 (25th ed. 1997). Cf. Model Penal Code $\$ 2.11(1)$ (consent a defense if it "precludes the infliction of the harm or evil sought to be prevented by the law defining the offense"); Markus D. Dubber, Model Penal Code 238-46 (2002).

${ }^{160}$ Hans-Heinrich Jescheck \& Thomas Weigend, Lehrbuch des Strafrechts: Allgemeiner Teil 380-81 (5th ed. 1996). 
environment" (sec. 29). The Model Penal Code similarly arranges the crimes defined its special part according to the "individual or public interests" they protect. ${ }^{161}$

By figuring in both the general part and the special part of criminal law, the concept of legal good highlights the connection between the two parts. Issues in the general part, like necessity, involve consideration of the same interests - or goods - that are protected by the offenses in the special part. This common conceptual foundation is obscured by the nomenclature in the Model Penal Code, for instance, which frames questions relating to legal goods in terms of "harms or evils" or "individual or public interests," depending on whether they arise in the general or special part.

In the end, the most important function of the concept of legal good may well be the facilitation of critical analysis, rather than critique itself. The very existence of the concept stands for the proposition that there are limits within which modern criminal law must operate if it is to claim legitimacy, and ultimately obedience and therefore effectiveness. The notion of legal goods provides critical analysis of German criminal law with a language for expressing itself, no less, but also not much more.

There is clearly a danger in overestimating the significance of the mere existence of a concept of Rechtsgut. Yet, one should also resist the opposite impulse to dismiss the concept as meaningless, or even hypocritical, simply because it has never been invoked to invalidate a single piece of criminal legislation. Even if the concept of a legal good turns out not to be constitutionally based, and therefore to have no destructive bite, it still can play a constructive role in a general account of the criminal law, perhaps even as a guideline for policy makers, and certainly as an interpretative tool for the courts. At the very least, it might be preferable to have courts ponder the question what legal good, or interest, a particular statute was designed to protect, rather than unsystematically divining the "gist"162 or "crux"163 or "gravamen" "164 or "focus"165 or "scope" "166 or "object"167 or "hard core"168 of a particular criminal statute, the "harm or evil,"169 just plain "evil,"170 or "injury" 171 it seeks to prevent, or the "individual or public interests"172 or "rights" "173 it is

\footnotetext{
161 "Offenses against the existence or stability of the state," "offenses involving danger to the person," "offenses against property," "offenses against the family," "offenses against public administration," and "offenses against public order and decency." See generally Markus D. Dubber, Model Penal Code 183-85 (2002)

${ }^{162}$ See, e.g., Kahtleen F. Brickey, Corporate and White Collar Crime: Cases and Materials 183 (3d ed. 2002) (federal mail fraud statute, 18 U.S.C. § 1341).

${ }^{163}$ See, e.g., People v. Sanchez, 2002 N.Y. LEXIS 2233 ("crux" of depraved indifference murder is extreme recklessness).

${ }^{164}$ See, e.g., Eisenstadt v. Baird, 405 U.S. 438 (1972) (distribution of contraceptives).

${ }^{165}$ See, e.g., Badders v. United States, 240 U.S. 391 (1916) (federal mail fraud statute, 18 U.S.C. § 1341).

${ }^{166}$ See, e.g., McNally v. United States, 483 U.S. 350 (1987) (federal mail fraud statute, 18 U.S.C. $§ 1341$ ).

${ }^{167}$ See, e.g., McNally v. United States, 483 U.S. 350, 358 n.8 (1987) (federal false statement statute, 18 U.S.C. $\S 1001)$

${ }^{168}$ See, e.g., People v. Dupont, 107 A.D.2d 247, 252 (!985).

${ }^{169}$ See, e.g., Model Penal Code. § 3.02.

${ }^{170}$ See, e.g., Salinas v. United States, 522 U.S. 52 (1997) (“distinct evil” of conspiracy).

${ }^{171}$ See, e.g., N.Y. Penal Law 35.05(2) (necessity defense).

${ }^{172}$ See, e.g., Model Penal Code $\S 1.02(1)$.

${ }^{173}$ See, e.g., Scheidler v. United States, 537 U.S. _ (2003) (property rights, Hobbs Act, 18 U.S.C. § 1951); McNally v. United States, 483 U.S. 350 (1987) (federal mail fraud statute, 18 U.S.C. § 1341; "intangible right of the citizenry to good government").
} 
meant to protect, or worse yet, to wonder which "class of persons"174 or "bad men" might have been intended to reach.

\section{Conclusion}

Though the tripartite analysis of criminal liability developed by German criminal law theory may not quite qualify as "one of the great achievements of the human sciences,",176 it has had a beneficial impact on Anglo-American criminal law. In particular, it has helped American criminal law to refine familiar common law distinctions between offense (consisting of actus reus and mens rea) and defense (consisting of justification or excuse) and to develop a general part of criminal law, setting out the conditions for criminal liability that apply to all offenses across the board, rather than to particular offenses (such as self-defense in homicide or claim of right in larceny). ${ }^{177}$ One need not believe in the possibility of a legal science to appreciate the value of analytic clarity and consistency. The German three-part analysis of criminal liability will not by itself produce the "correct" solution to a difficult case like Dudley \& Stephens, for instance, but it may well help crystallize the significant issues such a case raises.

The applicability of other, more substantive, aspects of German criminal law to Anglo-American criminal law is less straightforward. Thanks to its scientific self-image, German criminal law is not only remarkably complex, but also tends to a formalistic and somewhat insular preoccupation with taxonomy and conceptualization that is not easily compatible with the generally more pragmatic approach favored by Anglo-American criminal law, which is still driven by judges (and increasingly legislators), not academics, and must remain accessible enough to guide jurors' decisionmaking.

It is perhaps appropriate, therefore, that German criminal law's most important contribution to Anglo-American criminal law has been a formal one, the tripartite analysis of criminal liability and the rigorous distinctions between offense and defense, and between justification and excuse, that it implies. Still, even if the resolution of particular issues in German criminal law is not readily transferable to Anglo-American jurisprudence, the very ambition to construct a systematic and comprehensive account of criminal law represents a useful counterbalance to the particularistic case-by-case approach of the common law.

\footnotetext{
${ }^{174}$ United States v. Bajakjian, 524 U.S. 321 (1997) (federal currency reporting statute, 31 U.S.C. § 5322).

175 Ratzlaf v. United States, 510 U.S. 135 (1994) (federal currency reporting statute, 31 U.S.C. § 5322).

176 Enrique Gimbernat Ordeig, Sind die bisherigen dogmatischen Grunderfordernisse eines Allgemeinen Teils geeignet, dem heutigen Stand der Kriminalität, der Strafzumessung und des Sanktionensystems zu genügen, in Krise des Strafrechts und der Strafrechtswissenschaften?, at 152, 165 (Hans-Joachim Hirsch ed. 2001).

${ }^{177}$ On the relationship between the German tripartite system, the common law, and the Model Penal Code, see Markus D. Dubber, Model Penal Code $\S 3.2$ (2002).
} 